13 Murder of Retief and his men (6 February 1838) 


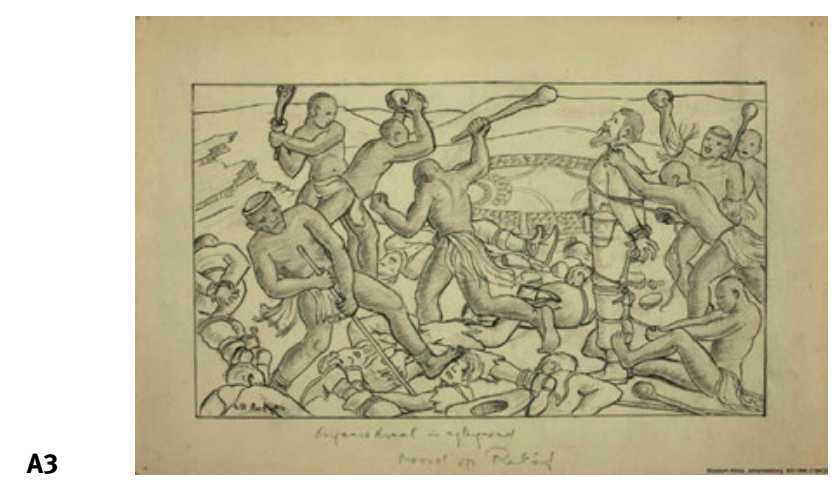

B2
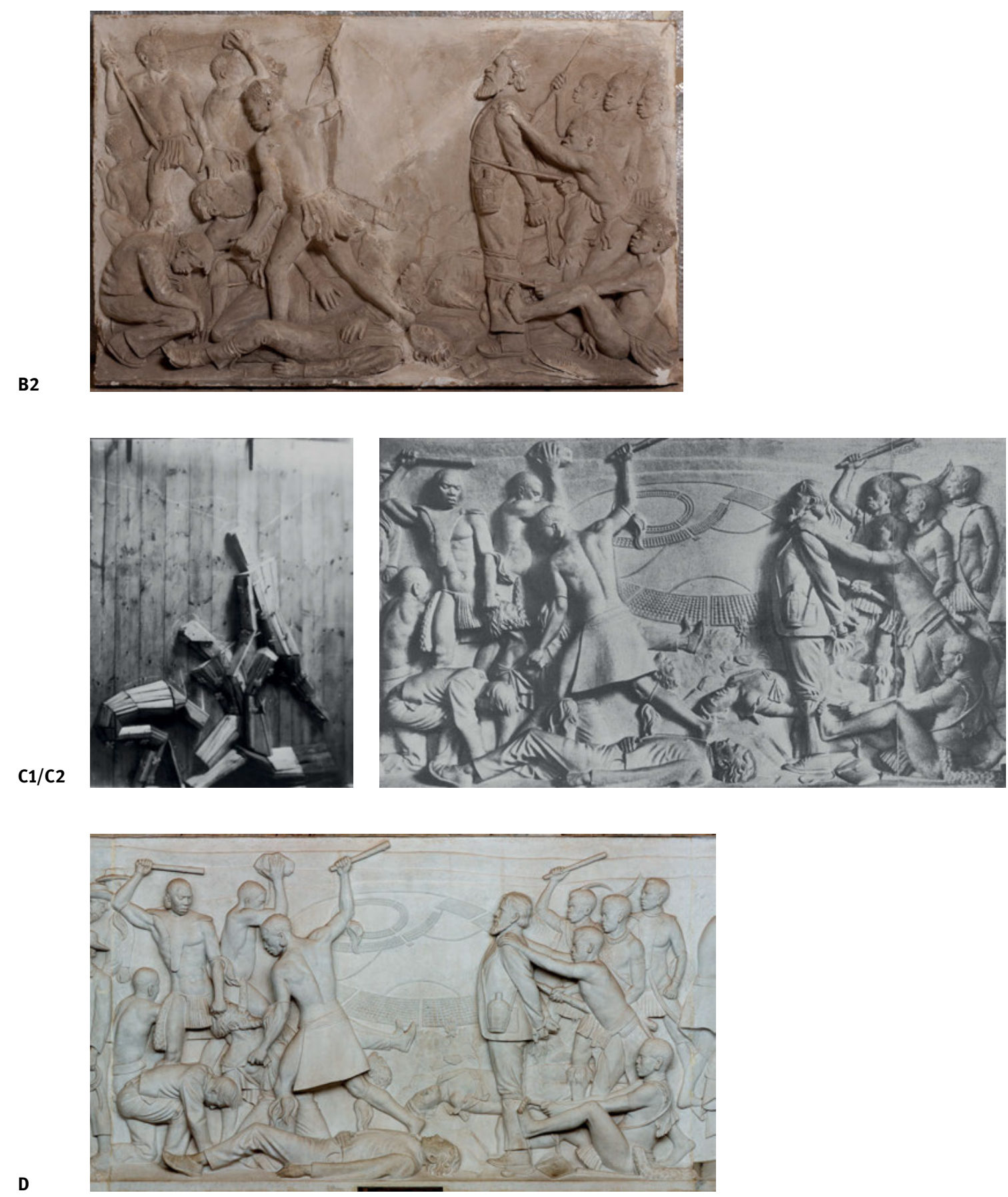


\section{Murder of Retief}

South wall, central scene (panel 16/31)

h. $2.3 \times$ w. $3.71 \mathrm{~m}$ (small overlap with panels 15 and 17)

Restored fractures on vertical edges

Sculptor of the clay maquette: Frikkie Kruger

\section{STAGES OF PRODUCTION}

A1 W.H. Coetzer, pencil drawing, retained only in A2 (April-June 1937)

A2 Reproduction of A1 (June 1937)

A3 W.H. Coetzer, revised pencil drawing A1, h. $13.5 \times$ w. $23 \mathrm{~cm}$ (after September 1937)

Annotations: 'DingaansKraal in Agtergrond' / (Dingaan's kraal in background) / 'Moord op Retief' (Murder of Retief)

A4 W.H. Coetzer, Die moord op Retief en sy manskappe (The Murder of Retief and his party); monochrome oil on board, h. $27.3 \times$ w. $46.6 \mathrm{~cm}$ (late 1937-38?)

B1 One-third-scale clay maquette, not extant but replicated in B2 (1942-43)

B2 One-third-scale plaster maquette, h. $75 \times$ w. $120.5 \times$ d. 8 cm (1942-43)

$\mathrm{C}^{\star}$ Full-scale wooden armature for $\mathrm{C} 2$, not extant but photographed (1943-45)

C2* Full-scale clay relief, not extant but photographed; replicated in C3 (1943-45)

C3* Full-scale plaster relief (1943-45), not extant but illustrated (Die Vaderland, 26.2.1945); copied in D (1948-49)

* were developed in two halves

D Marble as installed in the Monument (1949)

\section{EARLY RECORDS}

SVK minutes (4.9.1937) - item 4k (see below, 'Development of the design')

Voorstelle (5.12.1935?) - item 11 'Moord op Retief en sy volgelinge. Miskien kan ook hier gedink word aan die voorstelling daarvan in die rolprent, of soos 't op die bestaande Monument aan Moordspruit (Chieveley)' (Murder of Retief and his followers. Perhaps here the presentation in the film can also be thought of, or as it is on the existing Monument at Moordspruit (Chieveley) [see Bloukrans]) ${ }^{607}$

Panele (c. Dec. 1934-36) - item 5 'Moordtonele soos', a. 'op Piet Retief' (Murder scenes such as, a. of Piet Retief) Wenke (c. 1934-36) - item II. Dr. L. Steenkamp, mnre. A.J. du Plessis en M. Basson, A. 'MAATSKAPLIK’ (SOCIAL), 3. 'Verhouding met ander volksgroepe' (Relationship with other ethnic groups), d. 'Dingaan' (Dingane), vi. 'Afskeidsgroet en moord; spil waarom due [sic] lotgevalle van die Voortrekkers in Natal gedraai het' (Parting farewell and murder; the axis around which the fate of the Voortrekkers in Natal turned)

Moerdyk Layout (5.10.1936-15.1.1937) - scene 11 on panel 16 'Moord op Retief' (Murder of Retief)

Jansen Memorandum (19.1.1937) - item 7.11 'Massacre of Retief and his men, including the Englishman Halstead'

607 The reference to the Moordspuit Monument is misleading as its two marble reliefs both show the massacre of Boer women and children by Zulu in the area of Bloukrans, after they had killed Retief and his men at Dingane's residence. 


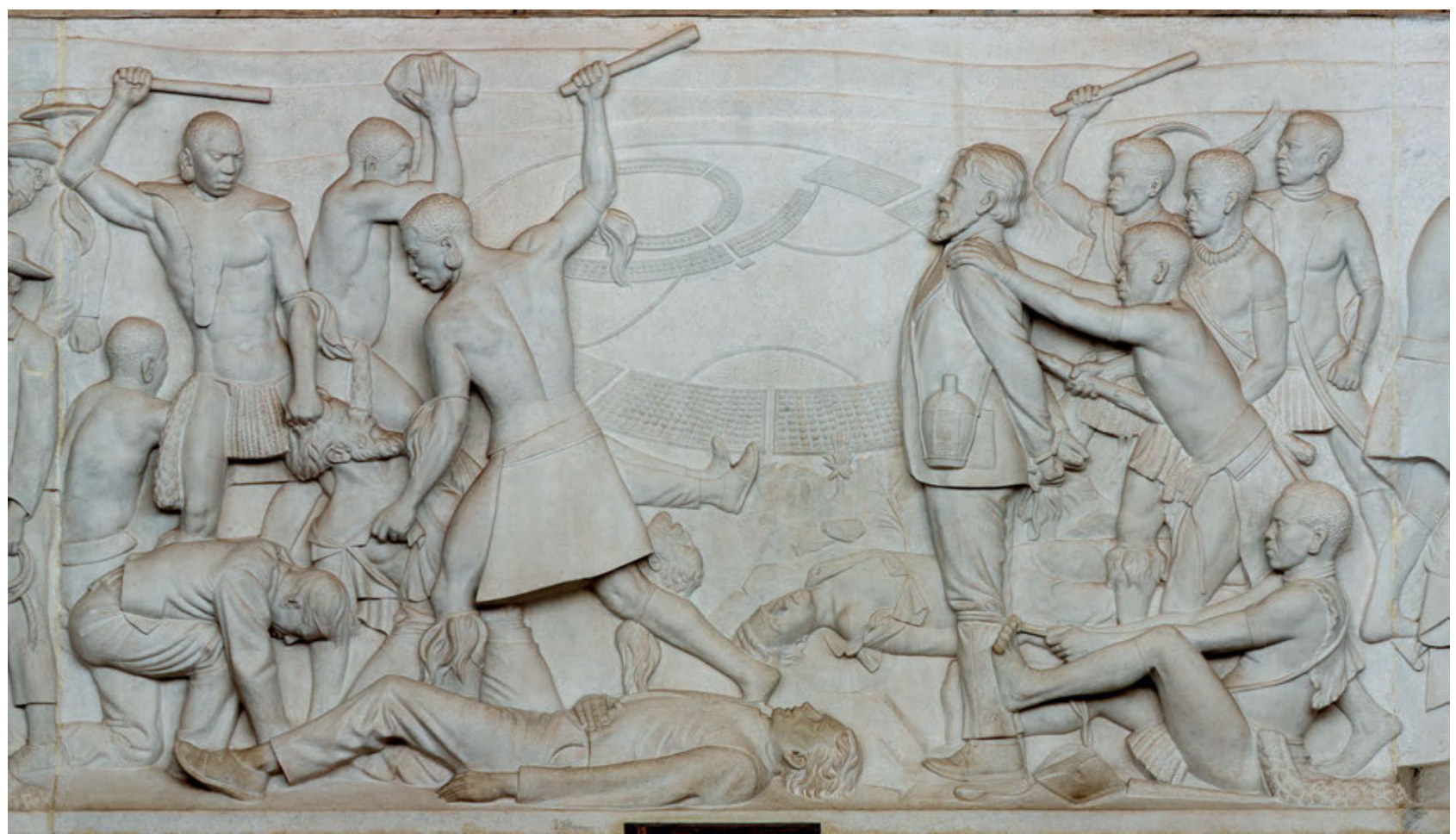

Figure 13.1: D. Murder of Retief. 1949. Marble, $2.3 \times 3.71$ m (courtesy of VTM; photo Russell Scott) 


\section{Description}

Nine Zulu club and stone seven Voortrekkers to death (fig. 13.1). The killing takes place on a rocky hillside (kwaMatiwane) with scant vegetation, which overlooks the huge Zulu capital uMgungundlovu in the background. The image is divided into three sections: an almost empty space in the middle allowing the view of Dingane's metropolis, with a group of adversaries on either side. The right group is dominated by the sole upright trekker who is bound and forced to stand erect, yet impeccably presented in a neatly buttoned jacket. This is the Boer governor, Piet Retief, who fixes his gaze upward, and has his fettered hands clenched in fists, suggesting indomitable will. A satchel lies behind his left foot, and on a strap over his shoulder is a bottle decorated with an ordered assembly of symbols around an arched aedicule (fig. 13.11), which we discuss in the appendix below.

Behind Retief are five Zulu, three forcing him into his upright position. One leans with all his weight on the Boer's shoulders; another behind him thrusts a stake forcefully into the Boer's back; a third seated on the ground braces his left foot against the Boer's leg, while he pulls back on the ropes tightly bound around his knees. The Zulu are all in traditional dress with lavish ornaments including earplugs, although they do not wear head rings.

Retief is staged in profile view next to the central opening, facing to the left and hence directing both his own and the viewer's attention to the slaughter of the Boers at the other side. On the ground between the two groups, the heads of three supine Boers meet from opposite sides in the centre. The Boer in the foreground, perfectly dressed, eyes almost closed, lies tidily on the lower edge of the panel, parallel to the picture plane, his left arm at his side, his left leg slightly bent. Further back on the other side, a second Boer has succumbed. He is young, his head fallen back, his flowing hair in disarray, and his jacket or shirt torn open over the breast, stressing his vulnerability. A third head to the left, this time bearded, appears to lack any body. Above this head a pair of disembodied legs emerge, indicating a fourth dead trekker.

On the left side four Zulu, two wielding sticks and one with a large stone, force two more Boers to the ground. The one in the foreground has sunk onto one knee, and his head and right arm droop in despair. The other Boer kneels, his stress captured in the dislocated appearance of his torso and hips and his harshly twisted head. The incoherence of this figure is heightened by the puzzling torn shirt or jacket with folded drapery beneath his arm. He is framed by two Zulu: one grips his hair to beat him to death, while the other grasps his torn shirt, his stick also raised high in attack. Further back a third Zulu crouches in rear view, while a fourth Zulu with strong back and arm muscles raises a rock, probably attacking the Boer whose lower legs alone are visible. The Zulu are uniformly violent, while the Boers are united in their passive habitus and emotionless expressions. None of them shows any sign of resistance or suffering, their demeanour reminiscent of unflinching saintly martyrs.

The centre background is dominated by an aerial view of the geometric layout of uMgungundlovu, oval in shape with hemispherical kraals placed in strict order around the circumference. The outer groups of kraals are divided by long straight passages that lead to the large empty space in the centre. The sole structure in the space is a perfect circle composed of four quadrants of small kraals, flanked by an arc of further dwellings, which act as a barrier to the inner sanctum, its only access through small passageways. 


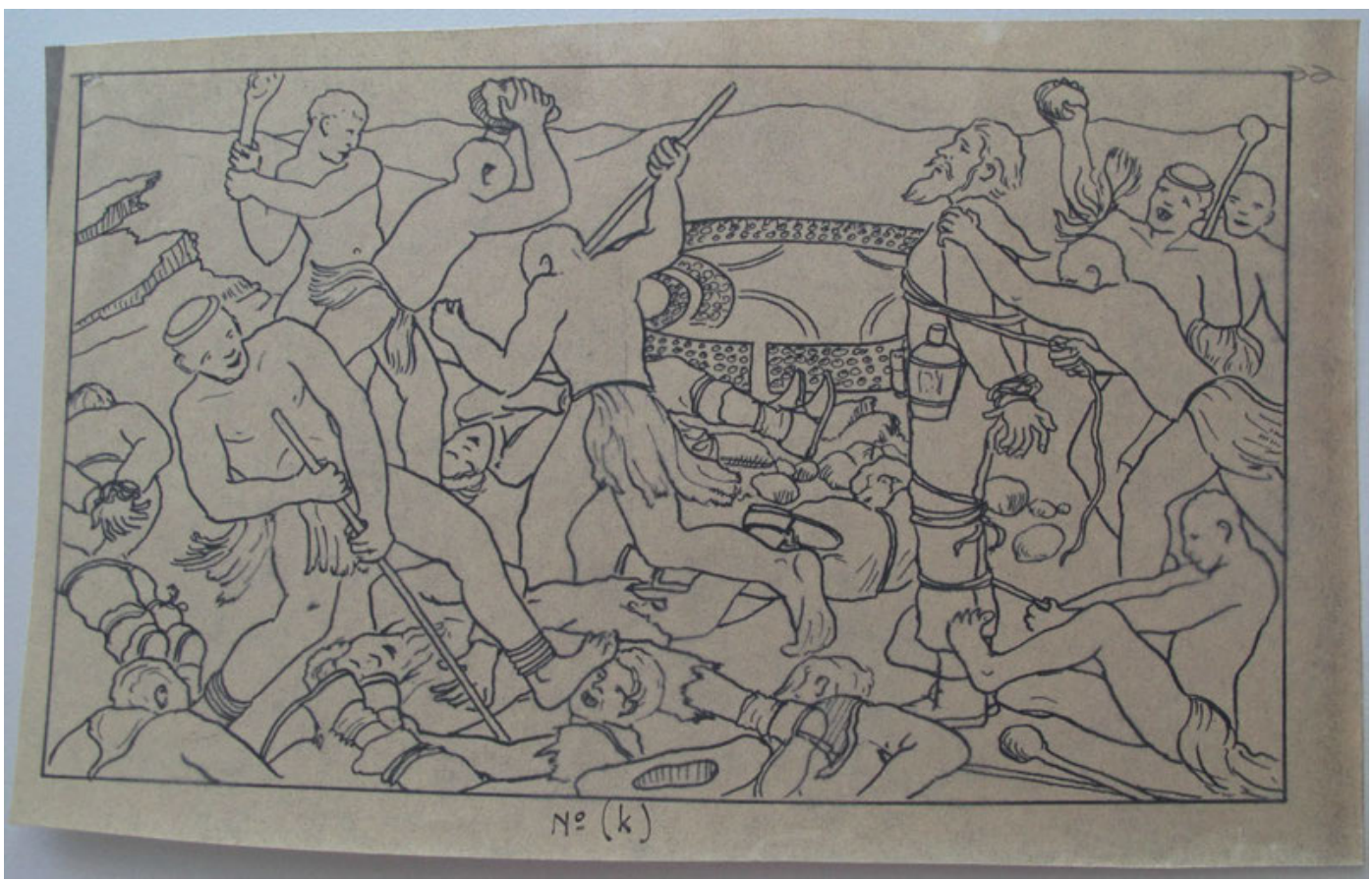

Figure 13.2: A2. W.H. Coetzer. Reproduction of first sketch for Murder of Retief. June 1937 (courtesy of ARCA PV94 $1 / 75 / 5 / 1$; photo the authors)

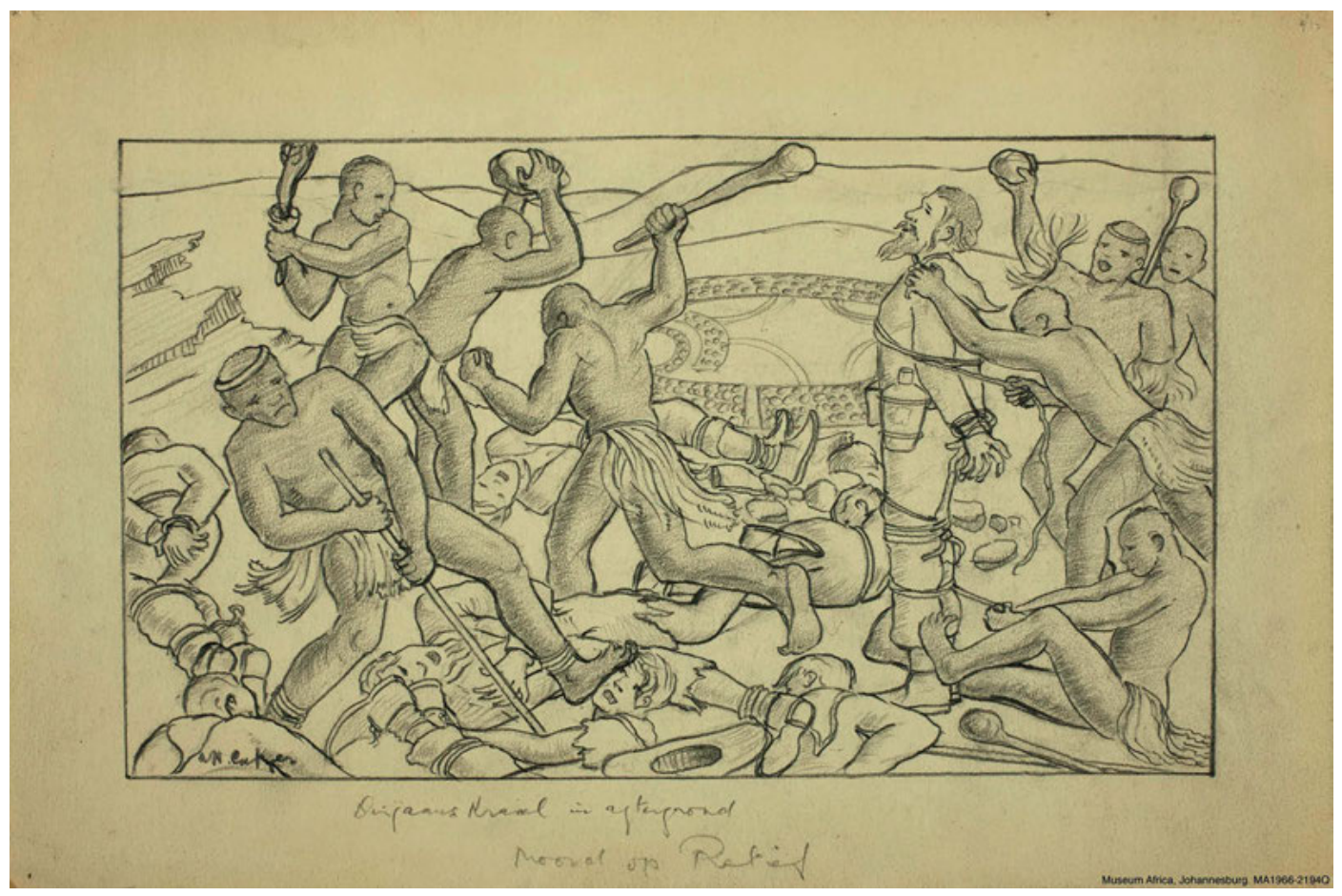

Figure 13.3: A3. W.H. Coetzer. 'Moord op Retief'. After September 1937. Pencil, $13.5 \times 23 \mathrm{~cm}$. Revised first sketch (courtesy of Museum Africa, no. 66/2194Q) 


\section{Developing the design}

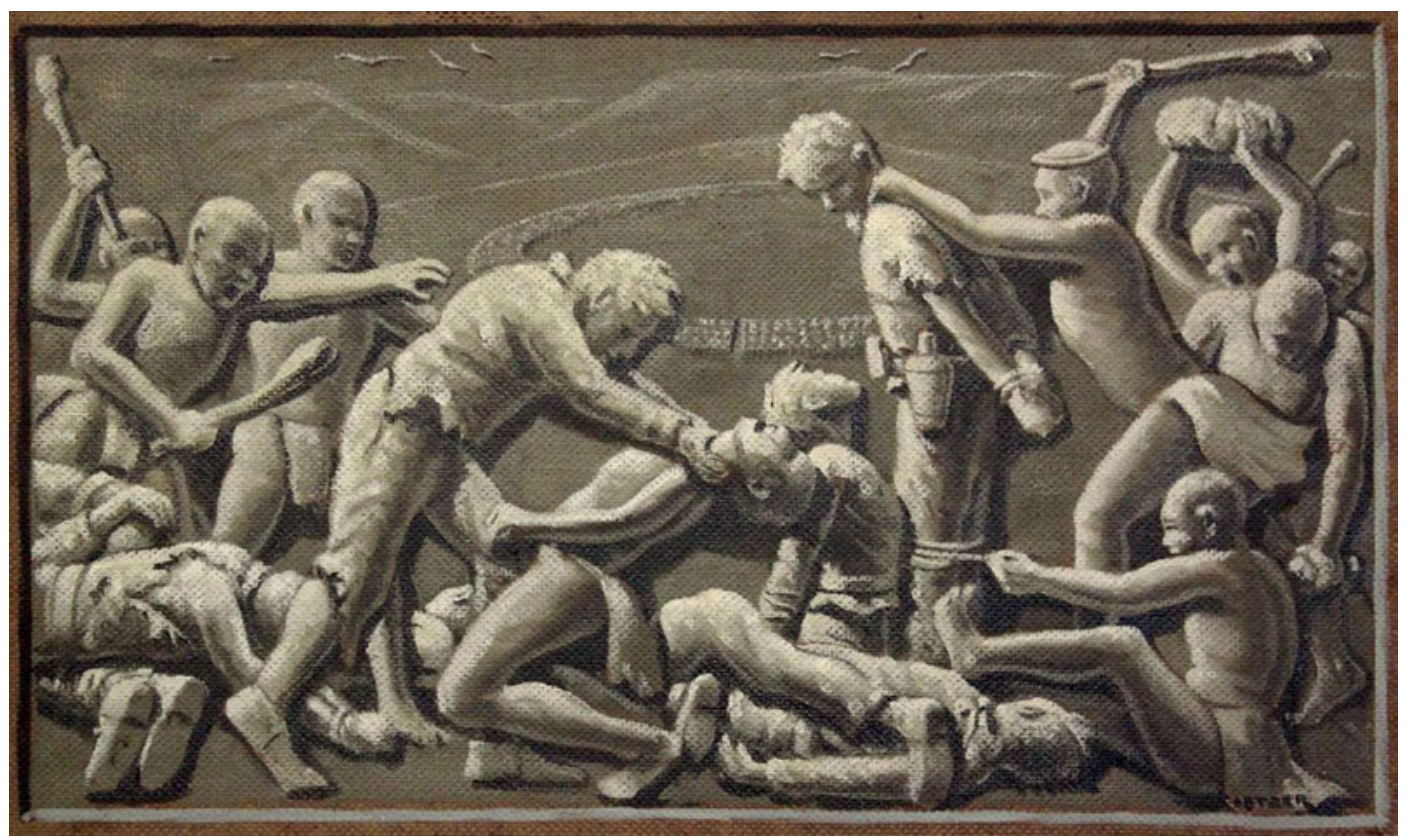

Figure 13.4: A4. W.H. Coetzer. Die moord op Retief en sy manskappe. Late 1937-38? Monochrome oil on board, $27.3 \times 46.6 \mathrm{~cm}$ (courtesy of DNMCH, OHG 901; photo the authors)

Again the Coetzer drawings provide the basic plot for the subsequent designs (figs 13.2, 13.3). He staged the scene on top of kwaMatiwane and divided it into three sections. On the right two Zulu force Retief, the sole Boer on this side, to stand upright. Important for the reading of the narrative is that he is shown with a flask on his left hip and, on his right, some sort of rectangular object partially visible beyond his jacket. This object is more distinct in Coetzer's monochrome painting of the scene (fig. 13.4) and was possibly intended to represent the leather container in which it is reported the treaty was found. On the opposite side four Zulu armed with sticks, stones and assegais are murdering seven trekkers, all forced to the ground, most of them young and bound. Coetzer shows some of the figures cut off by the frame, particularly in the foreground, to suggest the many Boers and Zulu involved. In the middle the significant gap between the two groups both emphasises Retief on its edge, and enables the beholder to look upon uMgungundlovu in the background (fig. 13.17) ${ }^{608}$ - the choice of an aerial view also suggesting the elevation of the killing field of kwaMatiwane. The fierce action of the Zulu and the extreme suffering of the Boers are more dramatically expressed than in the later reliefs. For example, Retief's writhing fingers suggest his anguish. In Coetzer's monochrome painting the emotional impact is even stronger. Here Retief no longer gazes aloft but looks down compassionately on his young son who, at his father's feet, strains to raise his head to gaze at him. Notable too is that one of the Boers fights back in this depiction and throttles a collapsing Zulu figure.

608 A painting of uMgungundlovu by Margaret Carey shows a similar view of the city; see Huisgenoot 1938, fig. after p.96 ('Painting by Margaret Carey in the care of the Historical Commission of the Saamwerk Union of the Natal associations. Originally owned by Dr. L.S. Steenkamp'). 


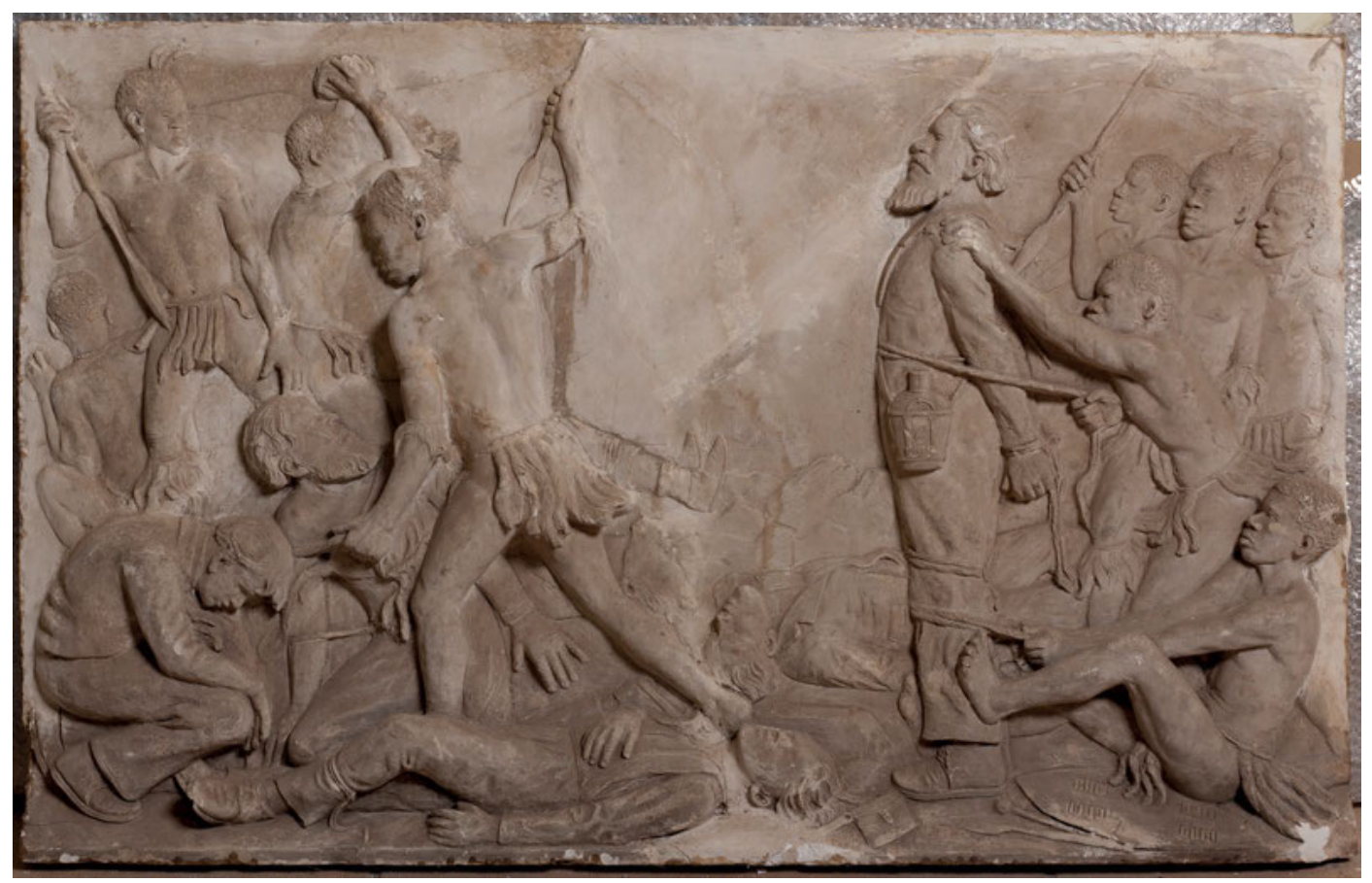

Figure 13.5: B2. Frikkie Kruger. Murder of Retief. 1942-43. Plaster, $75 \times 120.5 \times 8 \mathrm{~cm}$ (courtesy of VTM Museum VTM 2184/1-28; photo Russell Scott)

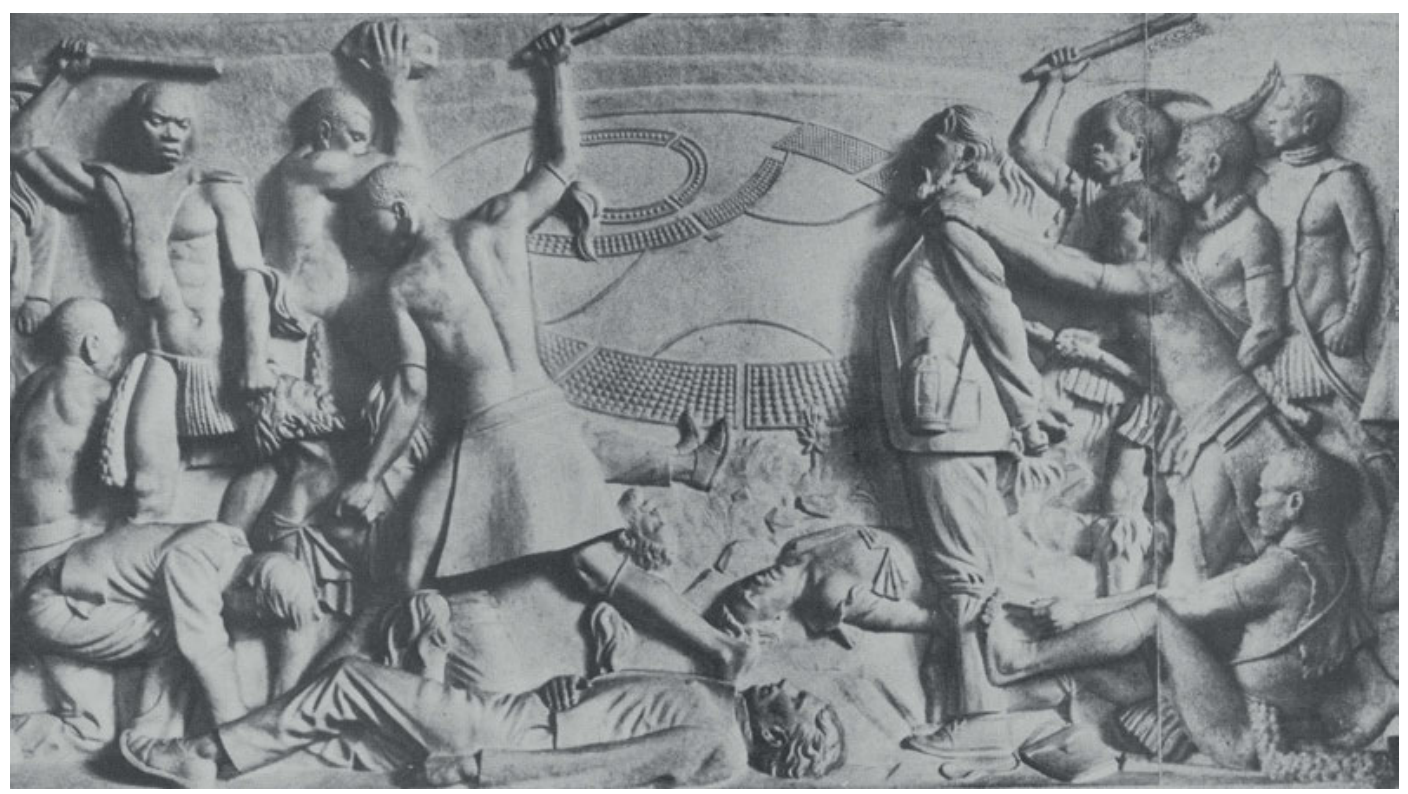

Figure 13.6: C2. Murder of Retief. 1943-45. Clay. Full-scale relief (Potgieter 1987, 24; photo Alan Yates, stitched) 
At the SVK meeting on 4 September 1937 the following alterations to the pencil sketch were requested:

Murder of Retief. The kaffers must be typical Zulus; they had sticks and not assegais; show that they handle implements (hitting things). ${ }^{609}$

Significant differences in the revised pencil drawing (fig. 13.3) from the reproduction (fig. 13.2) presented to the SVK are the more nuanced ranges of hills in the background and the shading of the Zulu to distinguish them from the Boers: it reveals Coetzer's oblivion to the sculptural purpose of the sketches, since this differentiation could not be deployed in a marble relief. Following the requirement of the committee is the erasure of the central assegai shaft in favour of a club (knobkierie), which changes that Zulu warrior's action from a downward stabbing to a more brutal swinging of the club.

In the maquette (fig. 13.5) modelled by Frikkie Kruger, Coetzer's composition is retained in a general sense but considerably changed and formalised in detail as there are fewer figures and the drama is reduced. The figures are more posed and frozen, and Kruger has created a tectonic composition, contained within the panel and avoiding Coetzer's cut-off figures at the margins. In the main, the number, distribution, motif and interaction of the figures are already close to the final marble. The foreground is now dominated by two Boers who crouch and lie on the ground. As in the drawing, Retief is separated from the fate of his men and stands erect with his head raised, a stoic figure who shows no emotion; his mouth is closed and his frenetic fingers have been controlled into clenched fists. He carries the bottle over his shoulder, decorated in a similar way to the final carved image, while a satchel is now lying on the ground in front of him.

As in the Coetzer drawing, the Zulu do not wear the war costume of knee-long aprons but a short version worn for dancing. ${ }^{610}$ But, as in his preliminary drawing, they are using mostly assegais to kill the victims, here clearly shown with blades, which is not in accord with historical records or Coetzer's revised version (fig. 13.3). The Zulu in the foreground of the drawing who ferociously stabs the Boer boy lying in front of him and tramples on his face is replaced by another who strides to the left behind the dying Boer to kill a trekker crouched helplessly in front of him. A disembodied pair of legs which was, in the drawing, part of a slain Boer in the background, now hovers bodiless behind this figure. The central gap between the two groups of figures is not yet filled with the aerial view of uMgungundlovu.

As with Inauguration, for the full-size clay panel (fig. 13.6) the sculptors had to deal with the tricky situation of developing one half of the scene at a time, because the support boards in Harmony Hall were only long enough to accommodate half of the full south frieze. This is even apparent in the armature, where a photograph of the left side has survived (fig. 13.7). Despite some later criticism that there was a hiatus between the two halves of the composition, discussed in Part I, ${ }^{611}$ it was in fact based on Coetzer's composition which Kruger had followed in the maquette, although the central area was extended a little, making the panel longer. And this provided the space for Dingane's stronghold, which was omitted in Kruger's maquette but reintroduced into the background of the full-size clay relief. A Yates photograph, taken while this panel was being made, shows several details still unfinished (fig. 13.8) when compared with a photograph of the final clay version (fig. 13.9); uMgungundlovu and the rocky terrain and its vegetation have not yet been modelled and the rendering of the clothing of the Boer lying dead behind Retief is incomplete.

609 'Die kaffers moet tipiese Zoeloes wees; hulle het stokke en nie asgaaie gehad nie; wys dat hulle 'n slaanding hanteer' (Historiese Komitee 4.9.1937: 4k). Coetzer does not, in fact, show the blades of assegais, so the weapons could be long sticks.

610 Gardiner 1836, 99-101, describes the Zulu dress of the time and illustrates different costumes such as war (drawing opp. p.101) and dance dress (frontispiece; drawings opp. pp.50 and 70); see Bird, Natal 1, 1888, 303-304.

611 Chapter 3 ('The full-scale frieze). 

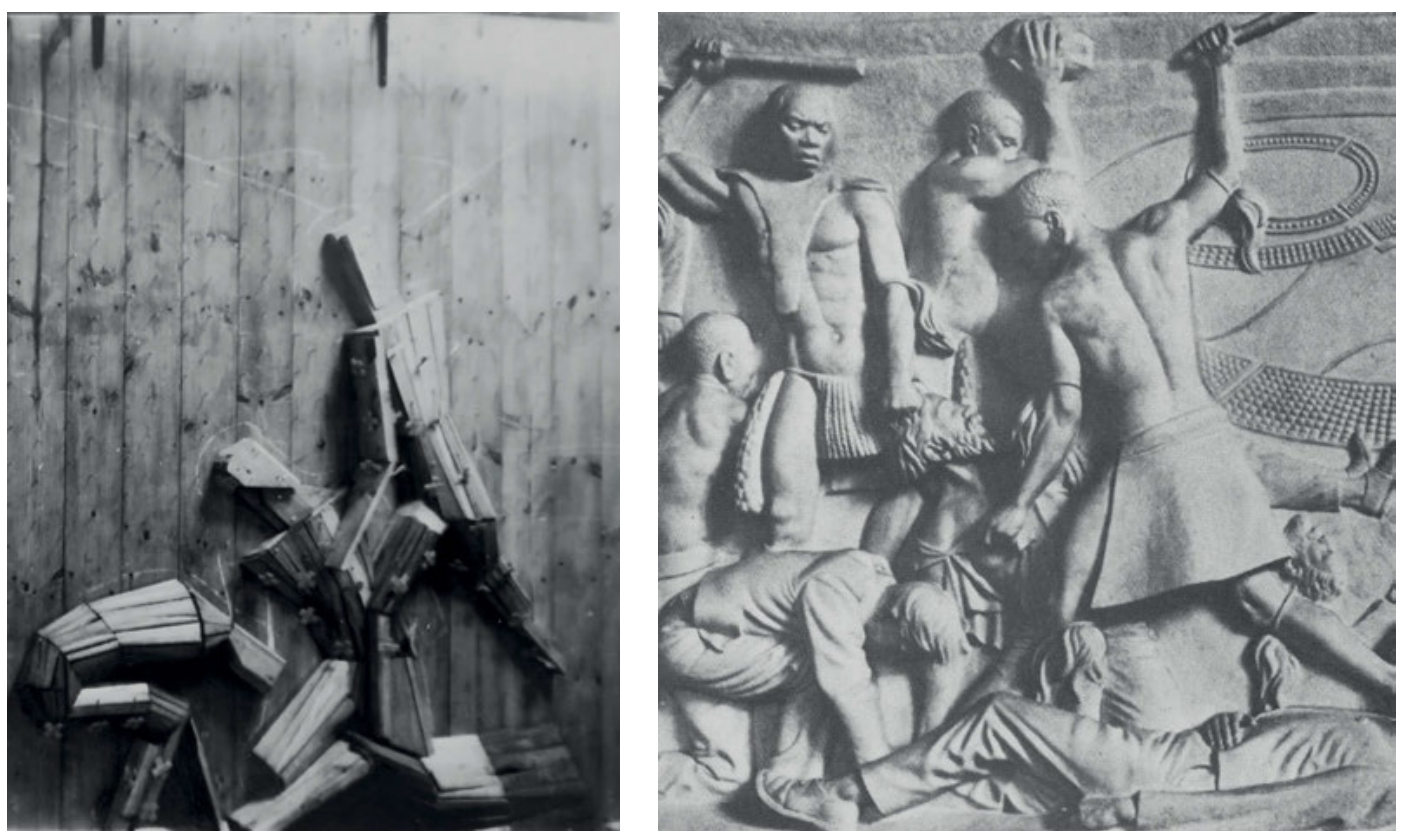

Figure 13.7: C1 and C2. Hendrik Ploeger. Left half of wooden armature of Murder of Retief (1943-45) compared with full-scale clay relief, detail of fig. 13.6 (courtesy of Kirchhoff files; photos Alan Yates)

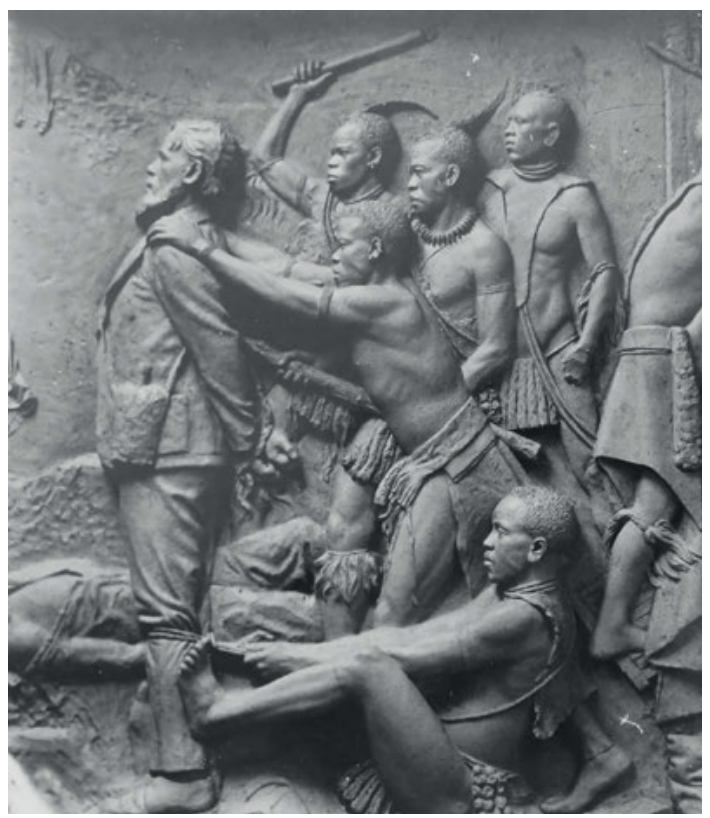

Figure 13.8: $\mathrm{C2}$. Murder of Retief, right half, partly finished state. 1943-45. Clay. Full-scale relief (courtesy of Kirchhoff files; photo Alan Yates)

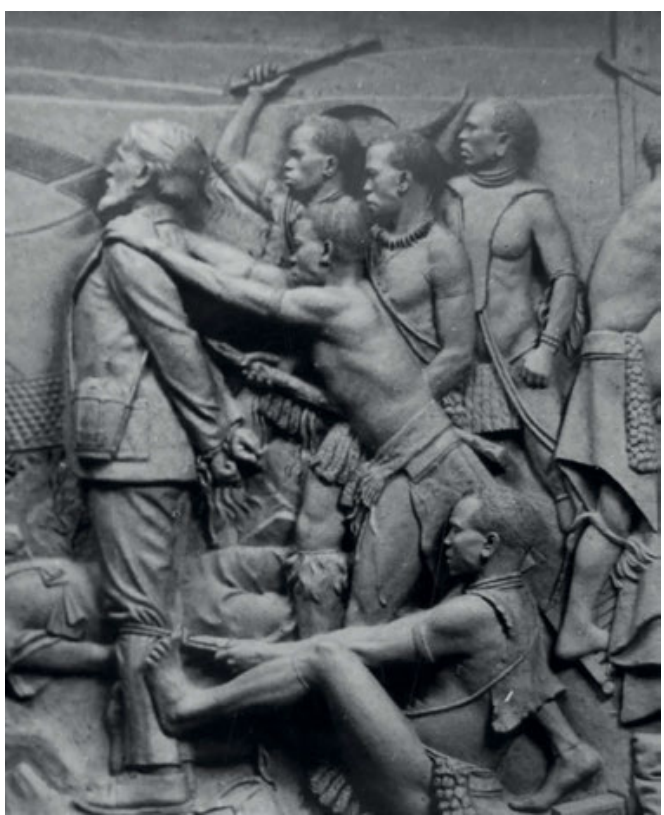

Figure 13.9: C2. Murder of Retief, right half, finished state. 1943-45. Clay. Full-scale relief (courtesy of Kirchhoff files; photo Alan Yates) 


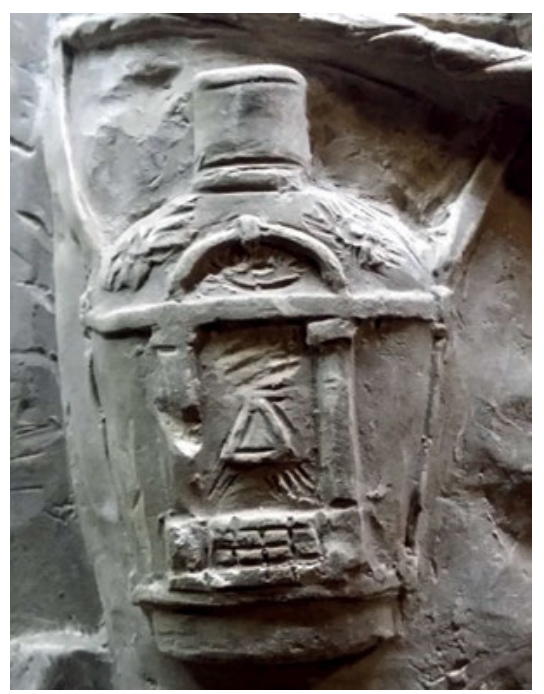

Figure 13.10: Retief's Masonic flask in Murder of Retief, detail of maquette, photographed in raking light as installed in 2017 exhibition (courtesy of VTM Museum VTM 2184/1-28; photo the authors)

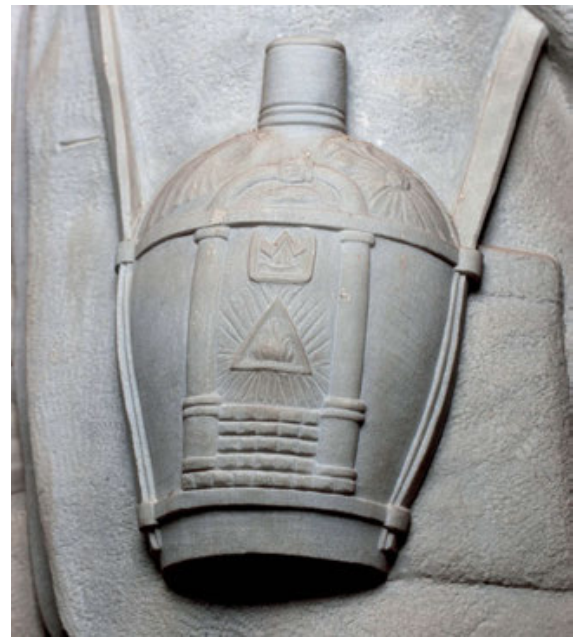

Figure 13.11: Retief's Masonic flask in Murder of Retief. Marble, detail of fig. 13.1 (photo Russell Scott)

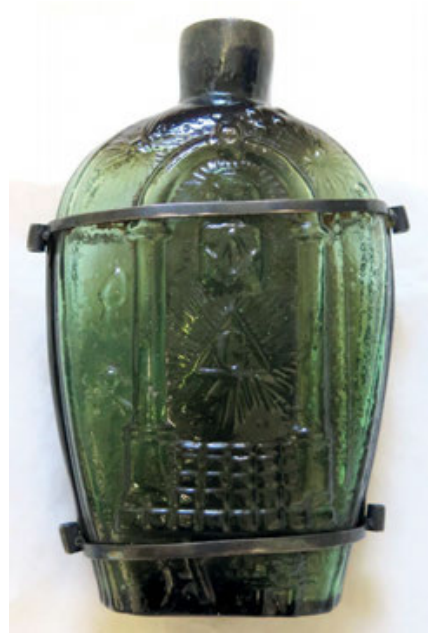

Figure 13.12: Masonic flask, GIV-4 type. c. 1815-30. Green glass, $21 \times 11.5 \mathrm{~cm}$. Keene-Marlboro-Street Glass Works, Keene, New Hampshire, USA (courtesy of uMsunduzi Museum Collection; photo the authors)

Also, Retief's flask is only roughly shaped, indicating that the flask must have been modelled late, after the narrative had been fully developed (figs 13.8, 13.9, 13.10, 13.11).

Changes from the maquette related chiefly to the representation of the Zulu. The warriors were clad in long aprons rather than short dancing skirts, and once again their assegais were exchanged for clubs and stones. The sculptors were apparently unaware of the Historiese Komitee's injunction that this should be done, for the SVK minutes in September 1943 record that Mr Faye, who had assisted in the correct depiction of the Zulu in Treaty, had also offered advice in this case, saying that according to Zulu custom assegais would not have been used in the murder. ${ }^{612}$ Overall, the process of formalisation continued, and was replicated in the final marble, so that the scene has an even more pronounced quality of being staged; of being a historical event frozen in memory.

612 'Mnr. Faye [or Feye] het hom [Moerdyk] ook baie goeie raad gegee o.a. (i) dat volgens kaffergewoontes by die moord geen asgaaie gebruik was nie' (SVK 30.9.1943: 3). 
Figure 13.13a: Topographic Sheets of South Africa (1:50 000). October 2010. Detail, showing uMgungundlovu with kwaMatiwane and Owen's hut at the sendingstasie (mission station) (map 2831AD)
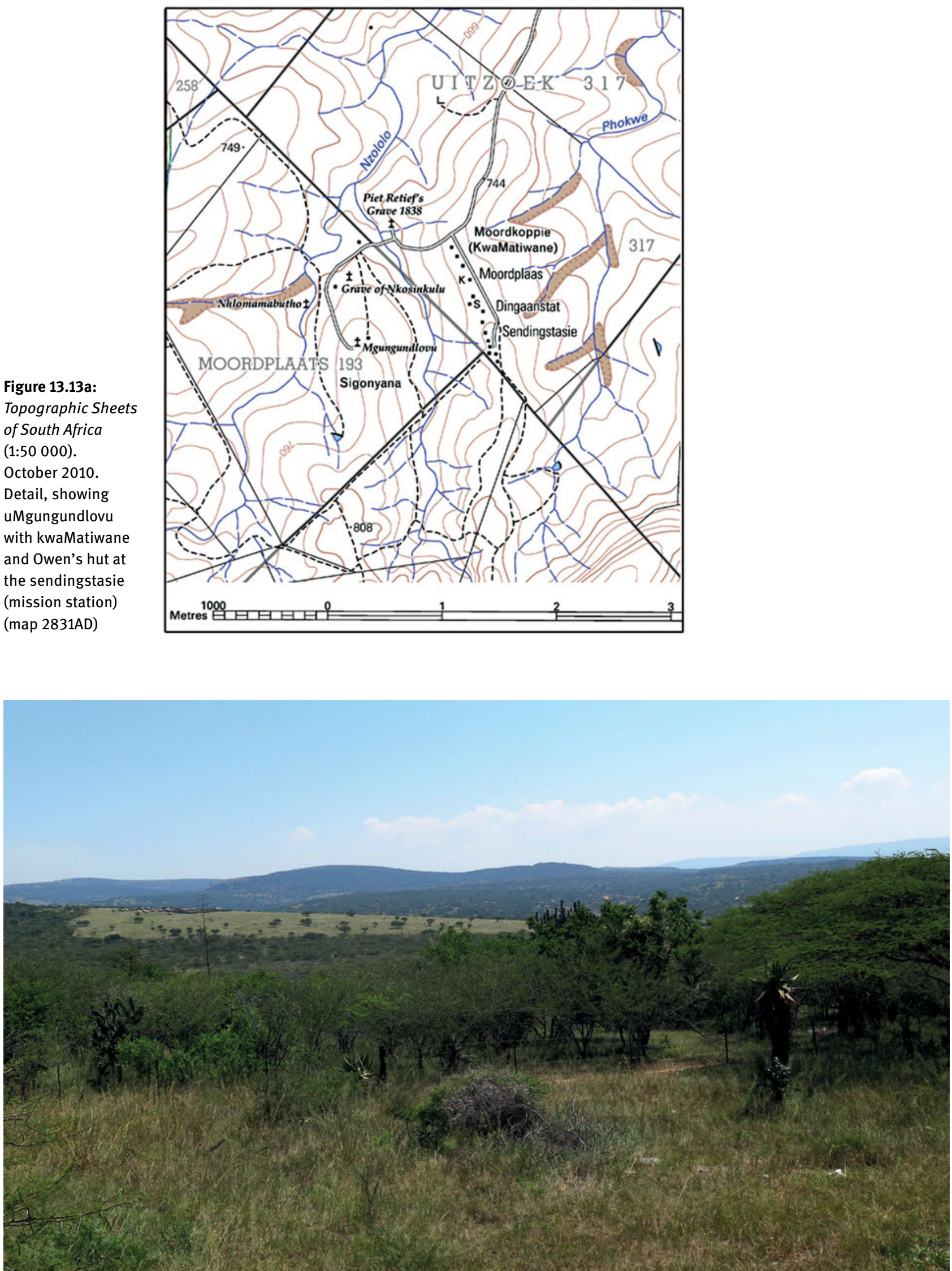

Figure 13.13b: View of uMgungundlovu from the area of Owen's hut. 2015 (photo the authors) 


\section{Reading the narrative}

The Murder of Retief follows directly after Treaty. As discussed in our account of the controversial evidence there, we have conflicting information about what happened when Dingane and Retief met on 6 February 1838, although the evidence strongly suggests that no land treaty was signed. For the subsequent massacre we have reports from three English eyewitnesses who were at uMgungundlovu: the missionary Rev. Francis Owen, ${ }^{613}$ and two people attached to his household, young William Wood, aged 'about eleven or twelve', ${ }^{614}$ and Jane Bird, neé Williams, who had accompanied the reverend from London. ${ }^{615}$ All three were at the mission station, a hut built on the same ridge as kwaMatiwane, east of Dingane's city (figs 12.13, 13.13a-b). They therefore had a view, albeit from more than a kilometre away, of both uMgungundlovu and the dread hill of kwaMatiwane, on which countless people had been executed by order of the Zulu king. ${ }^{616}$ For our context, the reports of Wood, Bird and Owen, and the later recollections of Zulu eyewitnesses discussed below, are crucial and deserve close reading. ${ }^{617}$ We begin with William Wood's Statements respecting Dingaan published in 1840 in Cape Town, about two years after the event, which offers the most detailed report of the murder on 6 February 1838:

Dingaan came out of his hut, and having seated himself in front of it in his arm-chair, ${ }^{618}$ ordered out two regiments ... These troops he caused to form in a circle, and, having placed his two principal captains on his right and left hand respectively, he sent a message to Retief, inviting him to bring his men, and wish the king 'farewell,' previously [sic] to starting. Retief a short time after this entered the kraal, accompanied by the other farmers and all their servants, with the exception of one or two, who were sent out to fetch the horses; their arms being left unguarded under the two milk-trees without the kraal.

On Retief approaching Dingaan, the latter told him to acquaint the farmers at Natal, as soon as he arrived there, of the king's desire that they should soon come and possess the land he had given them; also to remember him to them. He then wished the party an agreeable journey to Natal, and invited them to sit down and drink some 'tywala' [Kaffir-beer] with him and his people, which invitation they unfortunately accepted.

Retief sat by the king; but the farmers and their servants sat in a place by themselves, at a short distance from the king and his captains. After drinking some beer together, Dingaan ordered his troops to amuse the farmers by dancing and singing, which they immediately commenced doing. The farmers had not been sitting longer than about a quarter of an hour, when Dingaan called out: 'Seize them!' upon which an overwhelming rush was made upon the party before they could get on their feet....

The farmers were then dragged with their feet trailing on the ground, each man being held by as many Zulus as could get at him, from the presence of Dingaan, who still continued sitting and calling out 'Bulala amatakati' (kill the wizards). He then said, 'Take the heart and the liver of the king of the farmers and place them in the road of the farmers.' When they had dragged them to the hill, 'Hloma Mabuto, ${ }^{619}$ they commenced the work of death by striking them on the head with knobbed sticks

613 See Treaty.

614 Quote: Moodie 1888, 426. William Wood (DSAB 5, 1987, 897-898), born in the Cape Colony in about 1824, was the son of Richard Wood, a carpenter at Port Natal.

615 Moodie 1888, 425-430 (personal recollection, Jane Bird, neé Williams, 1877). Grobler (2011, 117-122) enumerates the conflicting reports of further contemporaries.

616 For kwaMatiwane, Bird, Annals 1, 1888, 282; Van Warmelo 1938; Kotzé 1950, 223-224 n 5; Becker 1979, 82-83, 203-204. We examined the topography of Owen's hut in relation to uMgungundlovu and kwaMatiwane in 2015, and confirmed Jane Bird's report (Moodie 1888, 425) that 'Dingaan gave us a location something less than a mile distant from his own residence'.

617 A short but measured account is provided by Kotzé 1950, 234-235.

618 Only recognisable if Wood used Owen's telescope.

619 Bird, Annals 1, 1888, 381 n *. 
[knobkieries], Retief being held and forced to witness the deaths of his comrades before they dispatched him. It was a most awful occurrence, and will never be effaced from my memory. The Rev. Mr. Owen and I witnessed it, standing at the doors of our huts, which faced the place of execution. Retief's heart and liver were taken out, wrapped in a cloth, and taken to Dingaan. ${ }^{620}$

It is impossible to judge the veracity of each detail in Wood's report, published two years later, considering his youth (which suggests that someone else must have transcribed the text for publication) and the lack of any comparable account. His position at Owen's hut certainly excludes any first-hand verbal recall of the communication between Dingane and Retief, as he cannot possibly have heard it (figs 13.13a-b). In contrast to the account of Jane Bird, his report reads as if he had been a bystander at the event instead of looking at it from Owen's hut. Here Bird's recollection in 1877 is more informative:

We looked out, and saw a great commotion in the chief's kraal, and a struggle going on. We saw that the Zulus dragged the Boers out of the kraal, and took them to the side of a hill, where the usual execution place was situated. If I had understood the Zulu or the Dutch language, I would have understood many of the exclamations which were made at the scene. I had seen executions take place at that spot eight days after we arrived, and at least four or five a week afterwards. I do not think half an hour elapsed between the seizing of the Boers and the end of their slaughter, and the return of the murderous executioners to the kraal of Dingaan. Scarcely had the Zulus left the place of slaughter when the vultures swooped down on to the bodies of the victims. ${ }^{621}$

Bird confirmed the clear view from Owen's hut on uMgungundlovu and kwaMatiwane. Her comment that she 'would have understood many of the exclamations' if she had knowledge of Zulu or Dutch suggests that the cries of both Zulu and Boers on kwaMatiwane could be heard over a considerable distance, but not normal communication in uMgungundlovu. Wood's and Bird's accounts of the events are for the most part confirmed by later recollections of Zulu eyewitnesses who were interviewed by James Stuart around 1900. The most important of them is Dingane's cuspidor (inceku), Tununu ka Nonjiya, who was present at Retief's death:

They [the Boers] went to the king early in the morning [of 6th February]. They arrived. Beer and amasi came from different sides. All came, leaving guns behind except 3 amalawana. They arrived and seated themselves. The king came to them. When they finished the beer and amasi the commotion (isidumo) occurred and they were killed. An inkondhlo was being sung and an ukuketa dance was being performed for them; they were surrounded. D.[Dingane] went suddenly at the back. Then the $u b e d u$ came together, i.e. the ring of people. They were killed with sticks, not assegais. They [the Boers] stabbed with knives. I was not stabbed. I did not strike them. The amabuto were hidden near the kraal; they arrived just as the disturbance began and in an extended movement. Being an inceku, I took no part in the slaughter. ${ }^{622}$

The report from Owen, the only one penned at the time of the event, contradicts some details in Wood's account, particularly in stating that the land treaty had not yet been signed. The missionary wrote on 6 February 1838 in his diary, published that year in the Church Missionary Record: ${ }^{623}$

A dreadful day in the annals of the mission! ... This morning, as I was sitting in the shade of my waggon reading the Testament, the usual messenger came with a hurry anxiety depicted in his

620 Ibid., 380-381. Hulley (1880, 9), who was not present himself, was told on 9 February that 'to prevent any resistance [from the Boers] their necks were at once broken; then their bodies were carried to the execution ground to be mutilated, then left to decay'.

621 Moodie 1888, 427.

622 James Stuart Archive 6, 2014, 260-261 (30.5.1903).

623 No. 10, Oct. 1838, vol. IX. The Graham's Town Journal published extracts of Owen's diary including entries for 2, 4, 6 and 7 February 1838 as early as April 1838 (Harington 1973, 44-45). And Hulley (1880, 7-9), Owen’s interpreter, provided a similar report after his return from Port Natal on 9 February 1838. 
looks. I was sure he was about to pronounce something serious, and what was his commission! ... a horrid instance of perfidy - too horrid to be described ... He [Dingane] sent to tell me not to be frightened as he was going to kill the Boers. This news came like a thunder stroke to myself and to every successive member of my family as they heard it. The reason assigned for this treacherous conduct was that they were going to kill him, that they had come here and he had now learned all their plans. The messenger was anxious for my reply, but what could I say? Fearful on the one hand of seeming to justify the treachery and on the other of exposing myself and my family to probable danger if I appeared to take their part. More-ever [sic] I could not but feel that it was my duty to apprize the Boers of the intended massacre whilst certain death would have ensued (I apprehended) if I had been detected in giving them this information. However, I was released from this dilemma by beholding an awful spectacle! My attention was directed to the blood-stained hill nearly opposite my hut, ... where all the executions at this fearful spot take place, and which was now destined to add 60 more bleeding carcases to the number of those which have already cried to Heaven for vengeance. There (said some one), they are killing the Boers now. I turned my eyes and behold! an immense multitude on the hill. About 9 or 10 Zoolus to each Boer were dragging their helpless unarmed victim to the fatal spot ... I lay myself down on the ground. Mrs. and Miss Owen were not more thunderstruck than myself. ...

Dingarn's conduct was worthy of a savage, as he is ... and being unable to attack them [the Boers] openly, he massacred them clandestinely! Two of the Boers paid me a visit this morning and breakfasted only an hour or two before they were called into Eternity. When I asked them what they thought of Dingarn, they said he was good: so unsuspicious were they of his intentions. He had promised to assign over to them the whole country between the Tugela and the Umzimvubu rivers, and this day the paper of transfer was to be signed. My mind has always been filled with the notion that however friendly the two powers have heretofore seemed to be, war in the nature of things was inevitable between them ... The hand of God is in this affair, but how it will turn out favourably to the Mission, it is impossible to shew. The Lord direct our course. I have seen by my glass that Dingarn has been sitting most of the morning since this dreadful affair in the centre of his town ... ${ }^{624}$

To Dingarn's message this morning, I sent as guarded a reply as I could ... I was quite ready to go myself; but Wm. Wood, my young Interpreter was too much petrified for me to ask him to accompany me. ${ }^{625}$

It happened that, just after the execution of the Boers, the American missionary Rev. Henry Isaac Venable, accompanied by his interpreter James Brownlee, 'reached the capital on Tuesday [6 February] at one p.m. ${ }^{626}$ and he provides another account from the time. The reverend wanted to talk to Dingane because Mungo, induna (headman) of Kongela, had 'issued an order forbidding the people, men or women, to attend our instructions'. Informed by the king's prime minister, Umhlela, about the killing of the Boers, he saw for himself 'the vultures ... hovering over their lifeless bodies'. ${ }^{627}$ According to Jane Bird, they had 'swooped down on to the bodies of the victims' as soon as the Zulu had left the place of slaughter. ${ }^{628}$ And when on 9 February Richard Hulley, Owen's interpreter, returned from Port Natal to uMgungundlovu, a week later than expected, he reported that he 'observed a large flock of vultures hovering over the place of the dead' ${ }^{629}$ In the end, more than a hundred people had been murdered, some seventy Boers, 'about thirty-eight achter-ryders

624 Hulley $(1880,10)$ reports that Dingane said to Owen after the murder: 'I was told also that you stood on the front of the wagon with your glass in your hand, and that when you saw what was going on [killing the Boers] you fell down in a faint, and were taken up insensible.' It shows that Owen and his small party had been under close surveillance. $\mathbf{6 2 5}$ Owen ed. Cory 1926, 106-109.

626 Kotzé 1950, 237 (for this and the following quotes). See also Bird, Annals 1, 1888, 216; Kotzé 1950, 10-16 (Henry Isaac Venable), 80 n 3 (James Brownlee); Becker 1979, 225-226.

627 Kotzé 1950, 237. Coetzer was possibly referring to the vultures when he painted birds approaching kwaMatiwane in his monochrome oil (fig. 13.4).

628 Moodie 1888, 427 (Jane Bird).

629 Hulley 1880, 7, confirmed by Owen ed. Cory 1926, 112 (9.2.1838). 
(grooms) and servants' and Thomas Halstead, the English interpreter. ${ }^{630}$ According to Hulley's recollection of 1880, Dingane justified the murder saying

... during your absence the Boers arrived; I kept them waiting as long as I could, expecting you to return with Capt. Gardiner and John Cane, but when I could keep them no longer I had put them out of harm's way. I see that every white man is an enemy to the black; every black man is an enemy to the white; they do not love each other, and never will. ${ }^{631}$

Murder of Retief broadly follows the narratives of the three English eyewitnesses, Owen, Wood and Bird, but the individual representation and general composition are filtered by Afrikaner intentions. The slaughter of Retief and his men is shown on top of kwaMatiwane, where executions ordered by Dingane took place. ${ }^{632}$ As reported by Wood, Retief is shown as the last to die, forced to witness the massacre of his people. The Boers are generally older in appearance than in the maquette, where the two foreground figures might have represented the young boys in the Boer party; whether one of the younger unbearded Boers in the final frieze was meant as a reference to Retief's son Pieter is possible but not recorded. It is significant that the marble diverges from Wood's account in an essential detail and follows the consistent recollections of Zulu eyewitnesses mentioned above. One of them, Nduna ka Manqina, reported on 27.4.1910 when he was about thirty years old:

The Boers came up, they came up outside the umuzi. They tried to surround Mgungundhlovu, but could not do so. He [Dingane] said, 'Do you see?' The warriors said, 'Let them be killed'. He said, 'I shall not order the men to carry assegais in case the Boers become suspicious.' He said, 'Ndhela, gather the men of the army. They must carry dancing shields [amahau], and not war shields [izihlangu], and also izikwili sticks. (Isiqayi - a very stout cudgel, not a knobbed stick (isagila), say 2 foot 6 inches in length). I shall hold a dance for them. I shall tell them, "I shall hold a dance for you. You will watch. After the dance I shall give you your cattle and you can take them away.”' He said, 'See, Ndhela, tell the men that two songs will be sung. At the second song I shall do this with my hand' [wave left and over the left shoulder]. The men of the Zulu sang. 'We have two, three inkondhlo dances; they wind about; they turn all over the place; we shall dance this way, and not that way' this is the chorus they sang ... Dignana waved his hand. Upon this the men of the army poured into the isigodhlo. For each Boer who died, one of Dingana's men died. They finished them off. That was where Piti died, the chief of the Boers. ${ }^{633}$

Like other Zulu, Nduna ka Manqina emphasised that the trekkers were executed with 'izikwili sticks', described in his report as 'very stout cudgels (isiqaya) ..., say 2 foot 6 inches in length', but not knobkieries as recounted by Wood, or assegais, the Zulu military weapon par excellence. The use of sticks was probably regarded as an act of severe humiliation. The Official Guide takes this for granted when it states that the trekkers 'were beaten to death with sticks and stones' ${ }^{634}$ Here it is the Zulu tradition which provided the sharper ideological edge for shaping the Afrikaner narrative of the Great Trek. And, accordingly, Moerdyk explains in the Official Guide,

630 For the assassinated victims listed by name, see Bird, Annals 1, 1888, 402 (quote); Nathan 1937, 212-213. A report of the only survivor of the massacre, a black servant of Retief, is quoted by Owen ed. Cory 1926, $47 \mathrm{n} 1$.

631 Hulley 1880, 8.

632 Moodie 1888, 427; Kotzé 1950, 223-224 n 5; Becker 1979, 82-83, 225-226.

633 James Stuart Archive 5, 2001, 7-8 § 27. For further Zulu reports, see James Stuart Archive 1, 1976, $319 \S 13$ (testimony of Lunguza ka Mpukane from 14.3.1909); 4, 1986, $263 \S 135$ (testimony of Ndukwana ka Mbengwana from 18.10.1897); 6, 2014, $253 \S 95$ (testimony of Tununu ka Nonjiya from 1.6.1903), 260-261 § 8-9 (testimony of Tununu ka Nonjiya from 30.5.1903).

634 Official Guide 1955, 49 (repeated in Heymans 1986, 22; Potgieter 1987, 24; Heymans and Theart-Peddle 2009, 27). Bantjes records for 21 December 1838, when Retief and his men were found at kwaMatiwane, 'the sticks and spokes [sic] with which they have been beaten, were found by thousands, ... some were those with which they danced, and some were poles wheron they built there houses, or wherewith they plant their fortifications' (Chase, Annals 2, 1843, 67). But no eyewitness mentions stones (or the impalement of Boers as claimed by Cilliers; see Treaty). 
Because assegais dared not be used in the royal kraal, they were beaten to death with sticks and stones. ${ }^{635}$ Retief was kept alive to the last, so that he might watch the martyrdom of his son, his friends and his servants. Then he was killed. At the order of Dingaan his heart and liver were then removed and buried in the path along which the Trekkers had come to the kraal. Retief is represented just before his death, fearless and defiant, with head erect, to symbolise the victory of European civilization over barbarism. ${ }^{636}$

Like the other Boers, Retief, their leader, does not show any expression of pain or emotion but only calm and composure - in contrast to their adversaries who look fierce or resolute. The facial control of the Boers is antithetical to their tortured bodies. In this respect they are portrayed as legendary heroes and martyrs who are stoic in the face of torture, similar to images of Christians being stoned or burned to death for their faith. This is particularly true of Retief (fig. 13.14), the only Boer still upright, who is forced by the Zulu to direct his gaze - and that of the viewer - towards the slaughter of his people. A religious reading of his martyr-like demeanour was not missed by commentators: Jan Gerritze Bantjes, one of the trekkers who reported on the finding of Retief's bones on about 21 December 1838, commented 'O horrible martyrdom!!!'637 and Cloete even called the hillock of kwaMatiwane 'the Boers' "Golgotha", ${ }^{638}$ The decision to portray the Boers as unresisting victims in the frieze underlined a concept of martyrdom, as opposed to portraying them fighting back, as Coetzer did in his monochrome painting, and as described by Erasmus Smit in his diary on 22 March that year:

The patrol from the camp of du Plessis has captured 2 spies of Dingaan, who have related that our Governor Piet Retief and all his men were killed without their having their weapons with them but that they defended themselves with their pocket knives, and killed a number of Kaffirs, and that Dingaan had them killed because His Excellency P. Retief had not brought back with them the head of Sekonyela. ${ }^{639}$

For the first time in the frieze, black people are the victors and white trekkers the victims, albeit as the result of treachery rather than a battle. And, in contrast to when Boers overcome Zulu, as in the Battle of Blood River, the rhetoric of defeat is so radical that not a single trekker can escape death. In Murder of Retief extinction is absolute. The motifs chosen to distinguish winners and losers can be related to different ancient traditions. While Retief has the unwavering habitus of Christian martyrs, the two supine Boers and the crouching trekker on the left echo motifs of defeated or dying figures from Hellenistic and Roman imagery (fig. 13.15). ${ }^{640}$ The Zulu, again, dressed in knee-length

635 But the only survivor of the massacre on 6 February 1838, one of Retief's black servants, recalls that Dingane's warriors used assegais which 'were all concealed in front of their feet when they sat. The dry dung and dust of the Kraal was piled over them ... My master was one of the last to fall. I saw the assegai pierce his breast, below the throat' (Cory 1926, 47 n 1). This seems to have been a common belief as Erasmus Smit (trans. Mears 1972, 134; Dutch text: ed. Scholtz 1988, 159) reports on 31 August 1838, when a Zulu prisoner was sentenced to death by the Boer Council, that our people 'will not torture you with 30, 40, and 50 stabs ["steken"], as you and your people have slowly murdered our people in the cruellest way; but your death will be short and compassionate'. The idea of the assegais hidden in the dust was used in the 1938 film Die bou van 'n nasie, where they were revealed as the Zulu danced and seen by Retief's son just before the attack.

636 Official Guide 1955, 49-50. The Council no doubt also had the Bloukrans massacre in mind.

637 Chase, Annals 2, 1943, 67; for Bantjes, see Naidoo 1985, 195, 200-201.

638 Cloete 1899, 100.

639 Smit trans. Mears 1972, 96-97 (Dutch text: Smit ed. Scholtz 1988, 125). That the trekkers were dependent on second-hand reports, because none of the Retief party had survived, meant that they had no certainty about Retief's fate, as demonstrated by another diary entry on 26 June (ibid., 118) that a black in the Maritz laager 'reported that the Old Boss (His Excellency Piet Retief) and 5 others sit alive in bonds with King Dingaan. Many reports, which we have, from time to time, heard concerning this matter agree with one another, but the whole matter still remains without certainty for us. May God grant that His Excellency and the others still alive [sic]!'

640 Stewart 2004, esp. 1-10, 171 fig. 193, passim. 

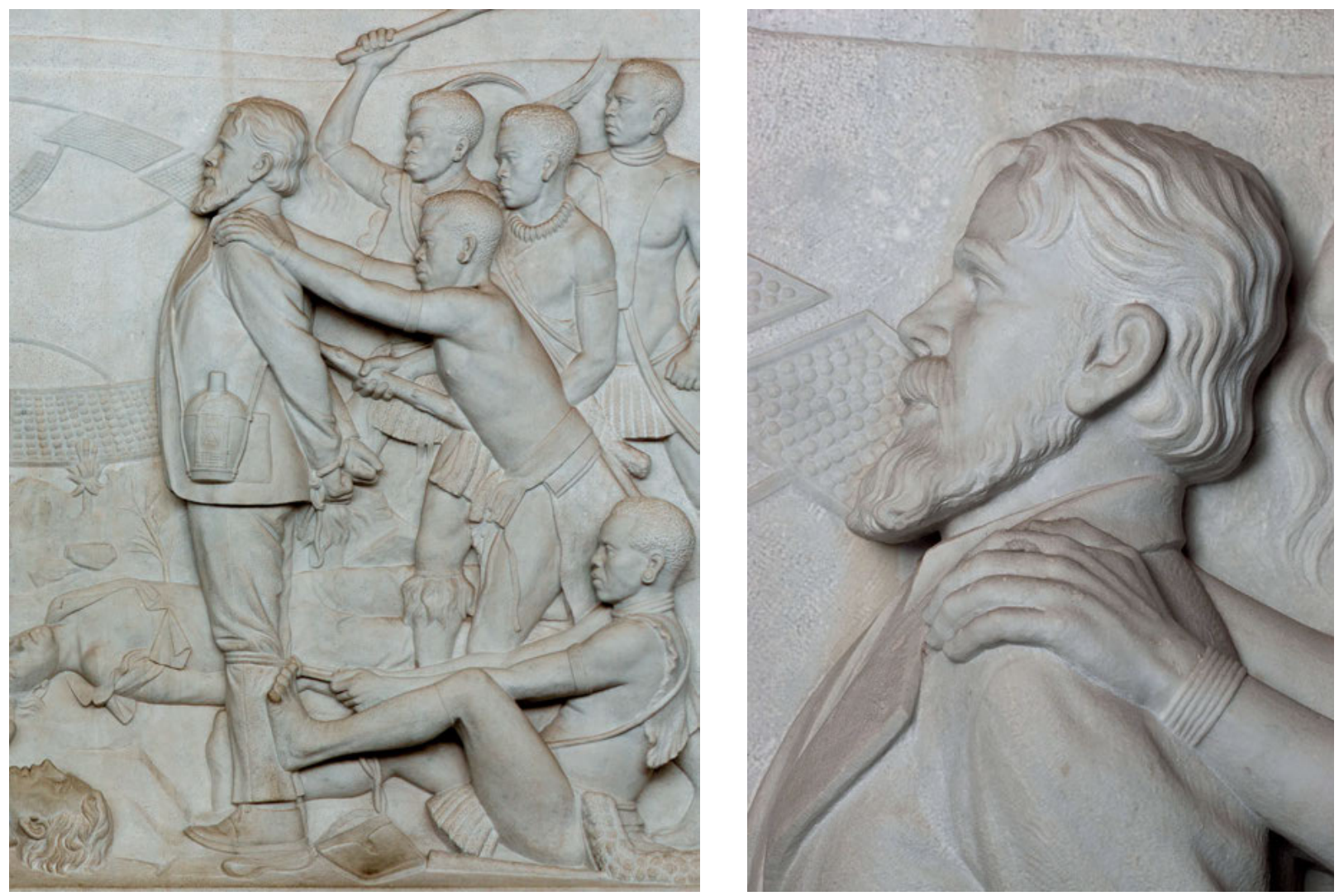

Figure 13.14: Retief as martyr in Murder of Retief. Marble, details of fig. 13.1 (photo Russell Scott)
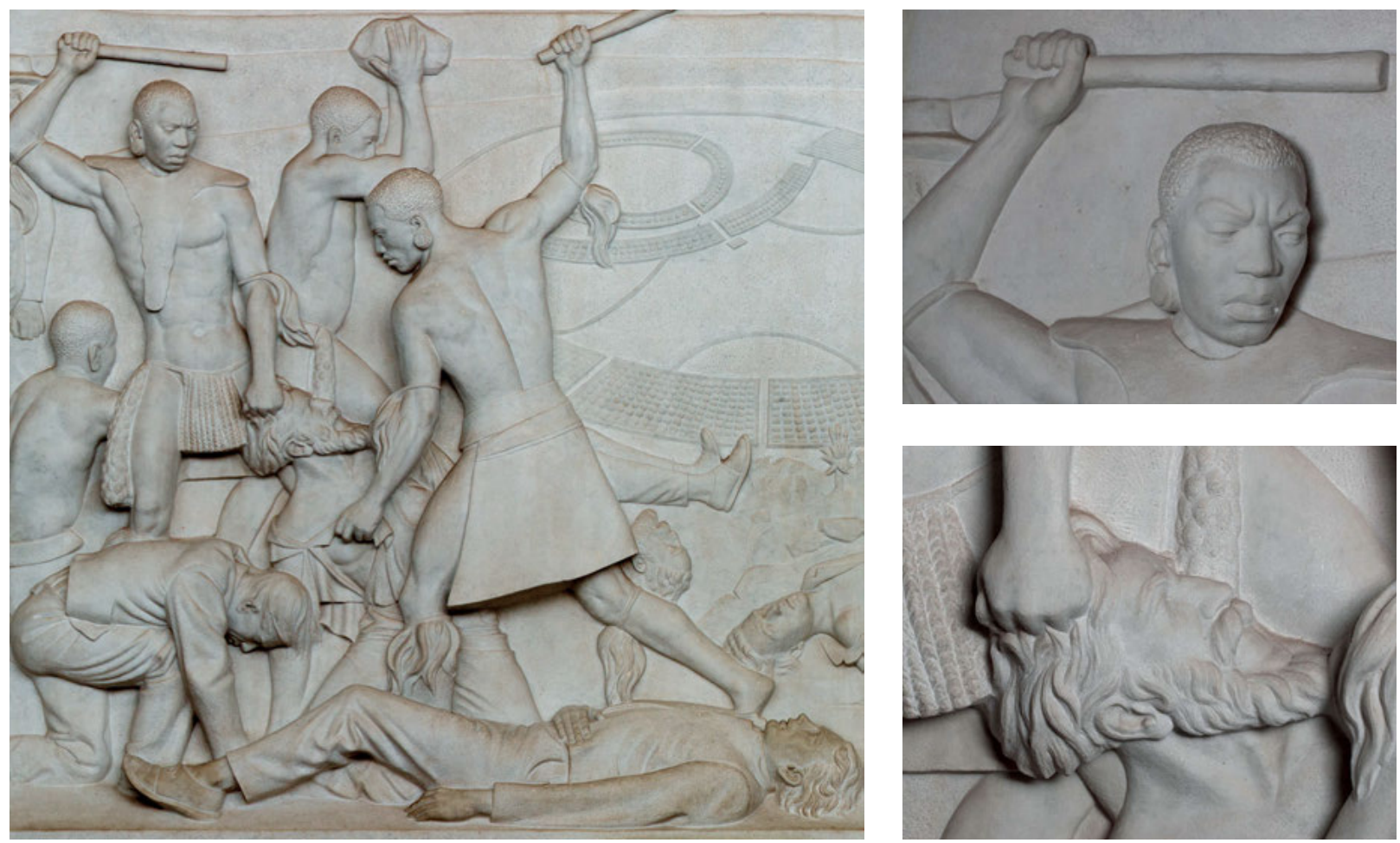

Figure 13.15: Zulu killing Boers in Murder of Retief. Marble, details of fig. 13.1 (photo Russell Scott) 
aprons and killing with raised sticks, are reminiscent of figures from ancient Egypt, especially the two on the left who grasp the hair or clothing of the collapsing Boer that they attack with their sticks, which recalls Pharaoh smiting the enemy. ${ }^{641}$ Whether the sculptors deployed these motifs deliberately or not is irrelevant. Important is the fact that their eclecticism, related to established ancient traditions, can colour the way viewers read the historical narrative of the frieze.

On 14 February 1945, when the finished plaster panels were provisionally installed in the Monument, a Rand Daily Mail reporter gained access to the Hall of Heroes. On the following day, as discussed in more detail in Bloukrans, he published a reproachful article under the headline 'Gruesome friezes in Voortrekker Monument' (fig. 14.23), in which he criticised the violence in Bloukrans and Murder of Retief. He remarks about the latter:

The martyrdom of Piet Retief and his comrades is illustrated by a picture of the Boers lying prostrate while savage warriors beat them to death with clubs and rocks. Retief is shown standing while his legs are bound.

These episodes could have been portrayed just as adequately if more subtle and impressionistic methods had been used. It is quite possible to do justice to the events without exciting passions of hatred and antagonism. ${ }^{642}$

It is an interesting indication of thinking of the time - even in a 'liberal' newspaper - that the scenes of black brutality to whites were considered offensive and likely to incite hostility, but no comment was made about scenes where blacks were the victims. Due to ongoing public and political pressure the obnoxious motif of a Zulu about to dash a little child against a wagon wheel in the plaster relief of Bloukrans, which the reporter had used to illustrate the article, was ultimately changed - while, less in the limelight, Murder of Retief attracted less attention and remained unaltered.

Two personal objects associated with Retief in the frieze distinguish the trekkers' first governor and commander-general: the satchel at his feet and the richly adorned flask that hangs over Retief's shoulder (fig. 13.14). The satchel is a topic of controversial debate, ${ }^{643}$ discussed fully in Treaty. Here it signals that the land treaty between Dingane and Retief had indeed been signed and stored away safely in the leather case, awaiting its discovery by Pretorius' men after the Boers' landslide victory over the Zulu in the Battle of Blood River.

The flask is based on one of green glass ascribed to Retief in the collection of the uMsunduzi Museum and Voortrekker Complex in Pietermaritzburg, which has been identified as a Masonic flask (figs 13.10-13.12). In the frieze its Masonic symbols have clearly been the model, yet they were either disfigured or omitted to obscure a clear reading. More or less accurately copied are the aedicule with its square-cut tiled pavement, the shape of the central triangle and the eye-like motif within the arch, both surrounded by rays. The alterations and omissions of well-known Masonic symbols are distinct: the letter ' $G$ ' in the triangle is replaced by flames; the open book with square and compass is disfigured into a meaningless zig-zag line; the keystone is now adorned with an odd bearded mask; the moon on the flask's left shoulder is transformed into a sun/flower with petals arranged like rays; the sickle-shaped ornament ending in four curved stripes on the opposite shoulder is incomprehensible. Omitted from the flask's decoration in the frieze are Jacob's ladder with the quarter moon surrounded by seven stars, the motifs of trowel and skull and crossbones next to the right column, and the crossed level cum plumb line and beehive below the pavement. W.H. Coetzer, who introduced the bottle in his drawing, merely indicates that there is some sort of decoration, but the small clay maquette depicts the general adornment of the flask as shown in the frieze: aedicule with pavement and keystone; blank triangle and eye, both partly framed by rays; the two ornaments on the shoulder, the sun/flower on the bottle's left and the unintelligible décor

641 Luiselli 2011.

642 NARSSA, BNS 146/73/3 (another copy is in Cape Town, National Library).

643 Naidoo 1985, 197-199. 
on the right (fig. 13.10). Yet it is close enough to the uMsunduzi flask to suggest that Frikkie Kruger, the sculptor of this scene, had access to the original bottle or a good representation of it, such as the one reproduced in both the 1935 and 1937 guides of the Voortrekker-Museum Pietermaritzburg. ${ }^{644}$

As already mentioned, one extant Yates photograph of the full-size clay panel in an incomplete state (fig. 13.8) shows the flask rough and unfinished with no details, and the background without Dingane's capital, which suggests that these details were left till last, while the figures are for the most part complete. A later photograph taken by Yates shows the completed relief (fig. 13.9); here, however, the flask is so out of focus that we can only identify the outlines of the aedicule with pavement and cornerstone, the triangle and eye, and the centre of the flower/sun, but no further detail. Our examination of the changes to the container's final form leads us to conclude that Moerdyk or the SVK were interested in using Retief's glass flask to identify him but, at the same time, kept the representation of Masonic imagery to a minimum. The likely assumption that Retief would not have carried a breakable glass flask when he visited uMgungundlovu on horseback - because if he had it would hardly have survived the brutal attack on his person and been preserved to become a museum artefact - adds a further layer of historical distortion to the scene, discussed in more details in the appendix, 'Retief's Masonic flask'.

The debate about Murder of Retief does not rest. A seemingly small matter in the minutes of the Dagbestuur in 1966 highlights the meandering and conflicting pathways of Afrikaner readings:

The secretary read to the meeting an exchange of correspondence with the Secretary of Coloured Affairs and between him and PP Stander and the Chairman in relation to the desirability or not of appropriately commemorating the 'agterryers' [grooms or servants] of Piet Retief who were murdered with the Voortrekker party. The meeting resolved that the letter of the secretary of 20 July 1966 to the Secretary of Coloured Affairs be approved and that it should also be noted that there is already a plate on the relevant panel in the Voortrekker Monument and that on it mention is made of the murdered 'agterryers' of Retief. ${ }^{645}$

Yet the plate on the relevant scene merely reads 'The Murder of Retief and His Men' and does not mention the slaughtered 'agterryers' ${ }^{646}$ One wonders whether the caption was kept deliberately general as 'his men' can be understood either inclusively or exclusively, depending on the political proclivities of the reader. There is little doubt, however, that in its Afrikaner context 'his men' refers to the Boers as no other victims are portrayed. One might surmise that, if the role of the servants was considered at all, it was felt that the inclusion of blacks amongst the murder victims here or in the succeeding Bloukrans scene would have undermined the predominant theme of the distinctive opposition of blacks and whites in the narrative of the frieze.

Unique in the frieze is the staging of Murder of Retief on top of a hill and the topographical connection to an aerial view on uMgungundlovu in the background (fig. 13.16), as shown, for example, in an etching by E. Whimper in Holden's 1855 History of the colony of Natal (fig. 13.17), ${ }^{647}$ and later mooted in Coetzer's drawing and in a number of his works (figs 13.3, 13.4) ${ }^{648}$ Without prior geographical knowledge, however, the relationship is almost impossible to understand and shows that the task of linking the two topographies with consistent perspective had overtaxed the capabilities of the sculptors. The view of uMgungundlovu is inaccurate, taken from roughly north-west of where kwaMatiwane is situated; the general organisation of the capital, however, is broadly

644 Basson 1935, 7 with fig.

645 12.2.1966: 8 .

646 Communication with the research staff at the Monument has not uncovered reference to any plaque other than the current one.

647 Oberholster $(1972,268)$ erroneously attributes this to 'Capt. Allen Gardiner: A Narrative of a Journey to the Zoolu Country in South Africa' (here Gardiner 1836).

648 It was also shown in Coetzer's depiction of Dingaanstat (oil, $23 \times 22 \mathrm{~cm}$ ), reproduced in Coetzer 1947 (fig. opp. p.199). 


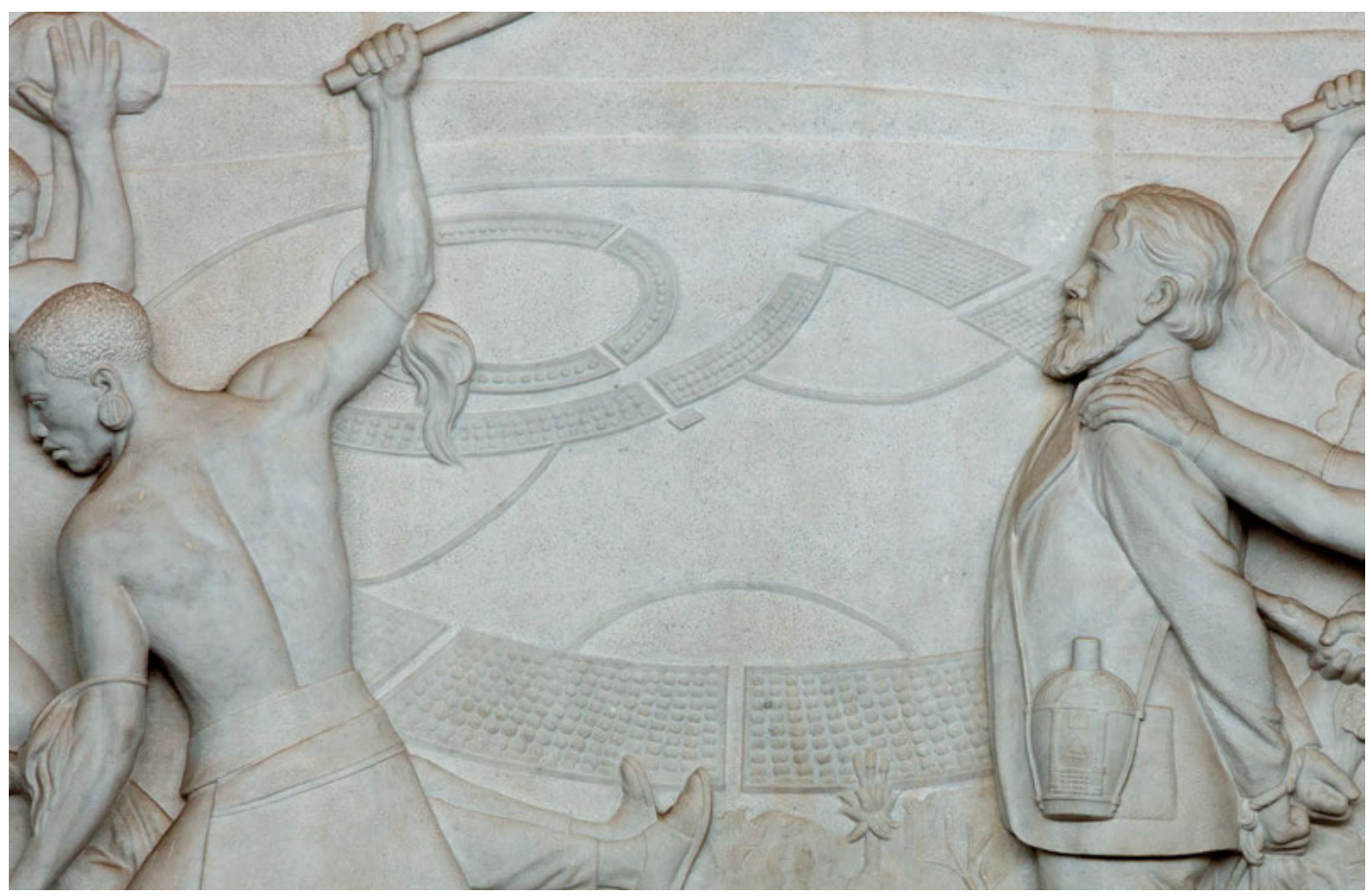

Figure 13.16: Aerial view of uMgungundlovu in Murder of Retief. Marble, detail of fig. 13.1 (photo Russell Scott)

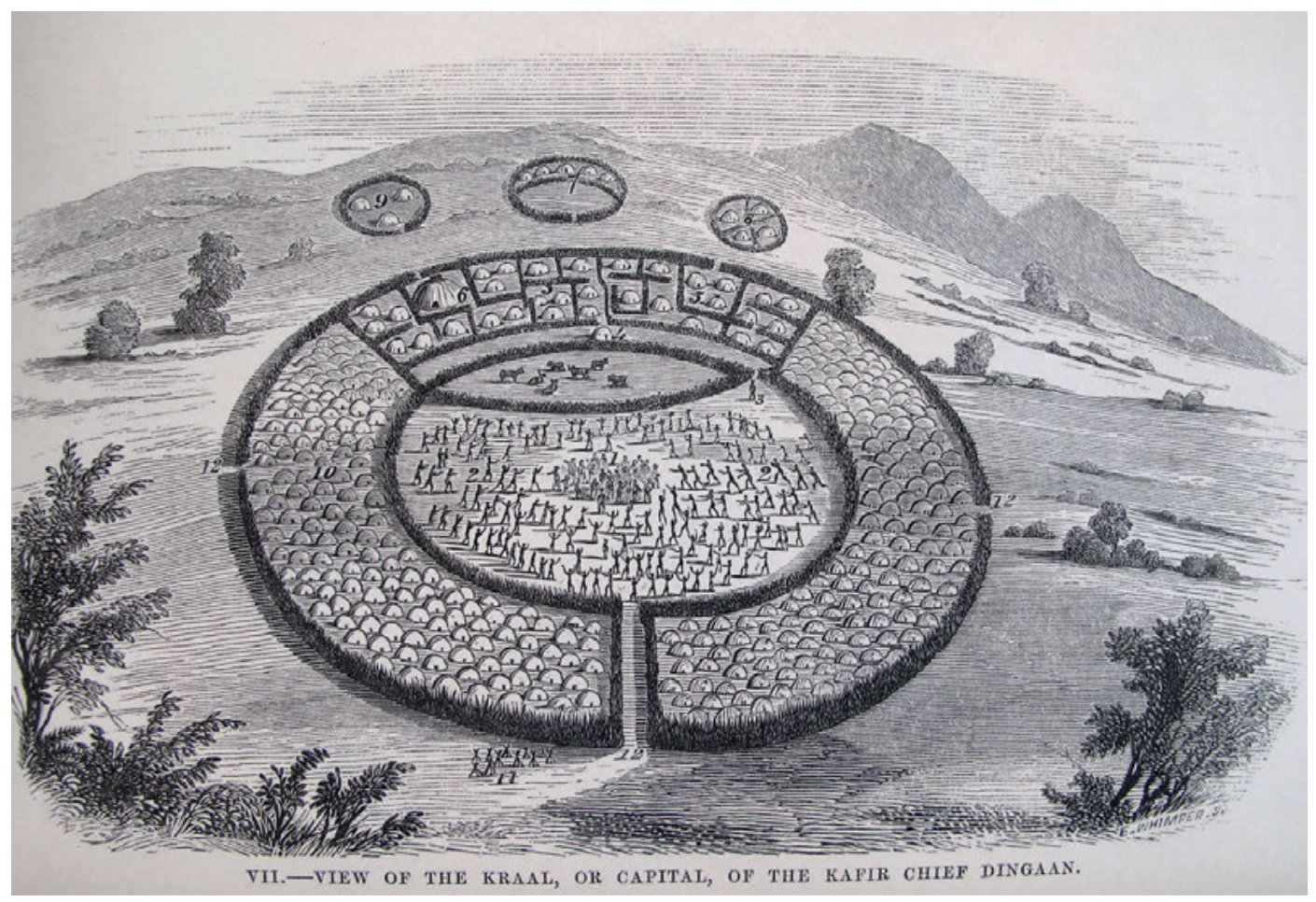

Figure 13.17: E. Whimper. View of the kraal, or capital, of the kafir chief Dingaan. Umgungundlovu. Etching (Holden 1855, opp. p.81) 


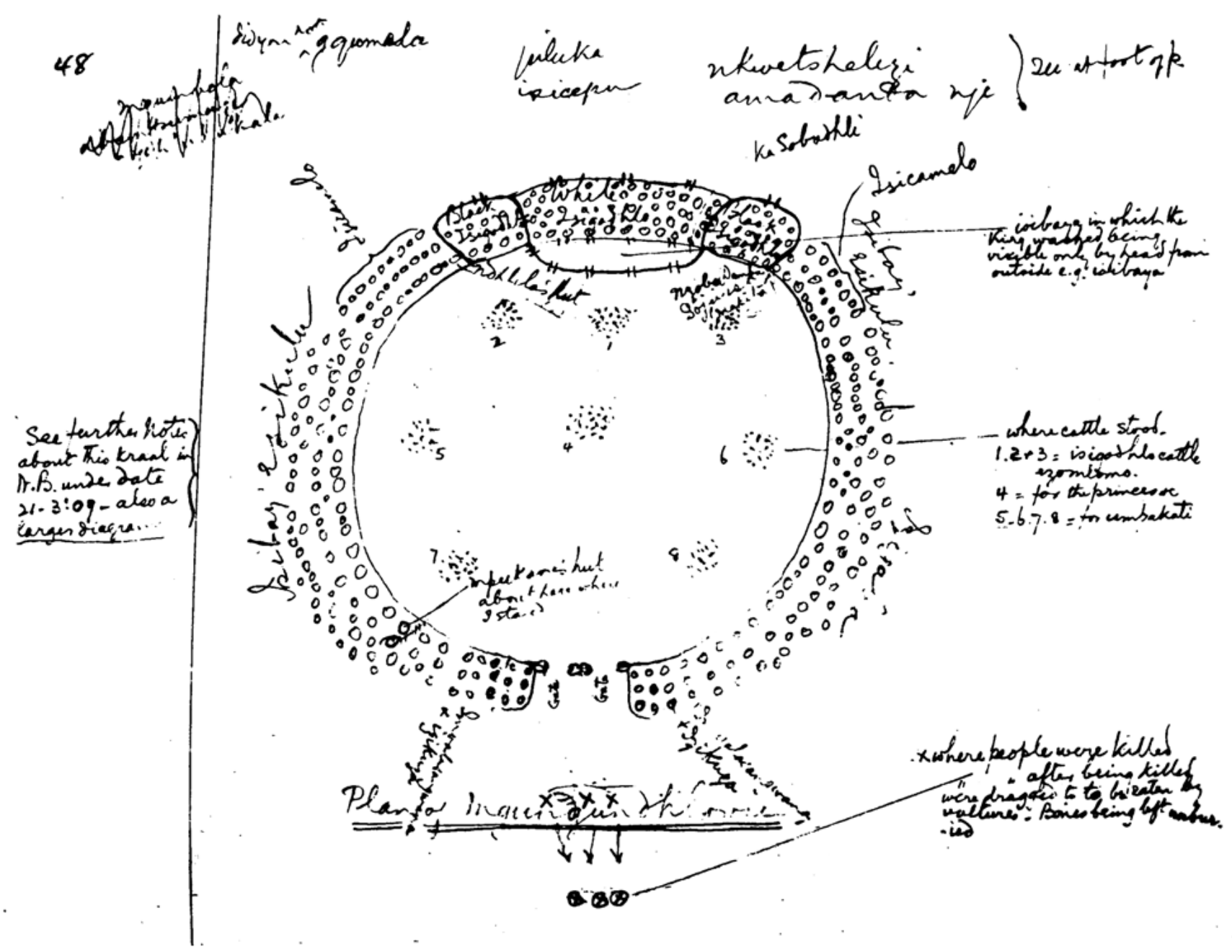

Figure 13.18: Sketch of uMgungundlovu following the recollection of Lunguza ka Mpukane, 11.3.1909 (James Stuart Archive 1, 1976, 309)

speaking correct, drawing on the available records, although details of the layout and inner structure are clearly idealised.

In 1829, after Dingane had taken part in the murder of his predecessor, King Shaka (c. 17871828), and himself occupied the Zulu throne, he had started to have his colossal capital built, naming it uMgungundlovu or emGungundlovu, 'the place that encloses the elephant'. ${ }^{649}$ It lay in the heart of the fertile and abundantly watered 'Valley of the Zulu Kings', situated about 110 kilometres east of present-day Ladysmith. While uMgungundlovu is known from early drawings and records, ${ }^{650}$ important additional information was published by John Parkington and Mike Cronin based on a review of the historical descriptions and the fieldwork carried out by the archaeological department of the University of Cape Town in January 1974 and July $1975 .{ }^{651}$ Before the close of 1829 Dingane moved into his new capital with large numbers of women and warriors. James Stuart

649 Laband 1995, 64.

650 Gardiner 1836, 200-201; Bird, Annals 1, 1888, 202-203 (Journal of Mr. Champion, 17 January 1836); Oberholster and Walton 1963; Oberholster 1972, 268-272; James Stuart Archive 1, 1976, 308-311 (interview of Lunguza ka Mpukane on 13.3.1909, who lived there at the time the Boers were killed and provided a detailed description of the residence); Muller 1978, 12 fig. 5, 55 figs 15-16, 58 fig. 27; Parkington and Cronin 1979, 133-136 figs 1-4; Laband 1995, 64-71; Raper, Möller and Du Plessis 2014, 515.

651 For here and the following, see Parkington and Cronin 1979. 
(1868-1942), who was born in Pietermaritzburg, brought up among Zulu speakers, and a 'Clerk and Interpreter to Resident Commissioner and Chief Magistrate', provides perhaps the most detailed and informative plan of uMgungundlovu (fig. 13.18) ${ }^{652}$ Roughly oval in shape, uMgungundlovu consisted of some 1100 huts, mainly for Dingane's warriors, which were arranged in either four, five or six rows like two horns framing a central area, a vast stretch of ground intended mainly for military celebrations: 'with maximum and minimum diameters of about $570 \mathrm{~m}$ north-south and $500 \mathrm{~m}$ east-west, with an area of about 22 hectares. The circumference would have been about $1.7 \mathrm{~km} .{ }^{653}$ At the top, or eastern section, and dominating the inner area, was the 'isigodlo' (royal enclosure) of Dingane and his large (female) entourage, cut off from the rest of the city by a thornbush hedge.

... Although all the huts of emGungundlovu were equally well built none was as large or attractive as the indlu enkulu, Dingane's private abode ... No less than twenty feet high and twenty in diameter the royal hut towered over the rest of the seraglio. It was built on an eminence so that at all times Dingane could view not only the entire settlement but also the country beyond, stretching to the hills on the horizon. ${ }^{654}$

Recent archaeological research confirms this description and adds important details about the structure of the capital. ${ }^{655}$ As regards the frieze, it seems remarkable that it includes such a specific rendering of uMgungundlovu, the stronghold of the enemy. In some ways it suggests the respect that Afrikaners had for the Zulu, but also that it was felt that the verification of Zulu detail would add to the authenticity of the Voortrekker story as a whole. More importantly, however, no other image in the frieze would have been able to capture the power of the Zulu people more compellingly than the representation of Dingane's residence. It emphasised the magnitude of the force the Boers eventually succeeded in breaking, shown in two triumphant scenes, Blood River and Death of Dingane.

652 James Stuart Archive 1, 1976, 309. In one of his notebooks Stuart described his objective 'to collect native custom so universally and thoroughly as to become an authority on it and compare it with existing legislation \&c., \&c.' (James Stuart Archive 1, 1976, xiii-xiv).

653 Parkington and Cronin 1979, 143.

654 Becker 1979, 79-80. A contemporary drawing of the interior is provided by Allen Gardiner (1836, opp. p.201).

655 Mitchell 2002, 373-376. 


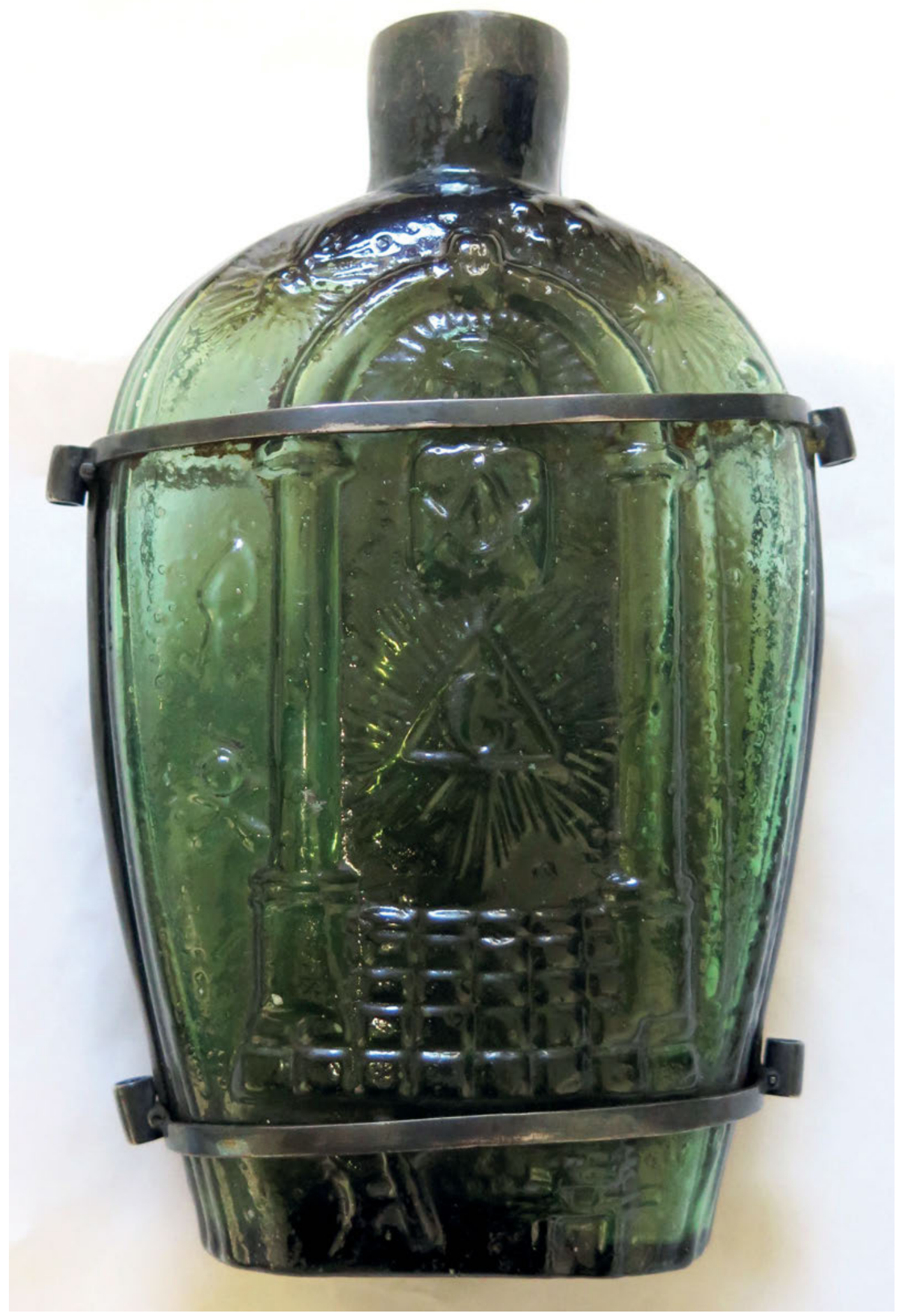

Figure 13.19: Masonic flask, GIV-4 type. c. 1815-30. Green glass, $21 \times 11.5 \mathrm{~cm}$. Keene-Marlboro-Street Glass Works, Keene, New Hampshire, USA (courtesy of uMsunduzi Museum Collection; photo the authors) 


\section{Appendix: Retief's Masonic flask}

\section{The flask's biography}

The flask reputed to have belonged to Retief is kept in the former Voortrekker Museum, now part of the uMsunduzi Museum Collection in Pietermaritzburg (fig. 13.19). ${ }^{656}$ Like a 'decanter flask' it is made of relatively heavy thick glass, 'clear forest green in color', ${ }^{657}$ and measures about $21 \mathrm{~cm}$ in height, with a width of $11.5 \mathrm{~cm}$ (mid-section) and $7.5 \mathrm{~cm}$ (base). ${ }^{658}$ On the eagle side the rim of the bottle neck is slightly damaged, and the flask shows numerous small marks of the production process. The container has vertically ribbed sides, a fire-polished finish, 'glass tipped pontil scar', ${ }^{659}$ and was blown in a two-piece hinge mould (see below) ${ }^{660}$ Later, metal fixings, to accommodate a strap for its user to carry it, and a silver bottle top were added.

The more elaborate front design - substantially changed in the frieze - is dominated by Masonic emblems, most prominently by an archway with keystone supported by two columns on high pedestals that stand on a pavement of 34 square tiles, ${ }^{661}$ a structure meant to represent the entrance to King Solomon's temple. The architecture is complemented by an ordered assembly of Masonic symbols. Between the columns is a radiant triangle enclosing the letter ' $G$ ' (standing for God or the Grand Architect of the universe), above it an open book with set square and compass in a rectangular format and, on top of that, God's radiant all-seeing eye. Alongside the right-hand column is "Jacobs ladder ascending to "cloudy Canopy" or "Star Decked Heaven", represented by radiant quarter moon surrounded by 7 stars at right of archway', ${ }^{662}$ complemented on the other side by a blazing sun. Left of the other column are a trowel, skull and crossbones, and, below the pavement, level cum plumb line and beehive. The decoration of the other side is less dense and apparently inspired by the US coat of arms (fig. 13.20). ${ }^{663}$ Below a decorative pennant is a frontal depiction of an eagle, the head turned to its right, holding a branch in its right claw that is not easy to identify, perhaps the Masonic sprig of acacia. Below the eagle the initials ' $\mathrm{v} \bullet \mathrm{K} / \mathrm{B} \bullet$ ' are framed by a horizontal oval with a bead-like pattern.

To the present day, the flask has been regarded as an extraordinary container for water and linked to Piet Retief by most. Helperus Hofstede called it his 'canteen' (Veldflesch), while in the first catalogue of the Voortrekker Museum in Pietermaritzburg it is classified as 'Piet Retief's

656 Illustrations rarely show the eagle (Becker 1979, fig. opp. p.209; Smail 1968, unpaginated, fig. bottom left, opp. 'Bible Presentation'), but usually the Masonic symbols: Hofstede 1876, drawing opp. p.50 (reproduced by Butler 1974, 280); Preller, Retief 1930, fig. opp. p.262, 363; Basson 1935, 7 with fig.; Huisgenoot 1938, 105 with fig.; Van Rooyen, Kultuurskatte 1, 1938, 163-164 with fig.; Groenewald and Bresler 1955, 53 with fig.; Voortrekkermuseum Pietermaritzburg 1955, 17 with fig.; Voortrekkermuseum Pietermaritzburg 1982, 21 with fig. The richly illustrated 1962 guidebook Voortrekkermuseum Pietermaritzburg (for the major part based on Basson 1935), however, does not include a photograph of the flask. One wonders whether it was perhaps suppressed because, as was possibly the case for the frieze, the bottle's Masonic decoration was regarded as inappropriate.

657 Email from Bill Lindsey (29.12.2018), a specialist of historical American bottles: 'Actually, after looking at the images again, along with some other more pure "clear olive green" flasks and bottles I have, I would lean towards calling it a "clear forest green" in color ... Those heavier flasks would have held up better to their use as a canteen as most other flasks of the time.' We gratefully acknowledge his detailed advice about US Masonic flasks of the earlier nineteenth century in general and the Pietermaritzburg example in particular.

658 Information kindly provided by Elrica Henning (Head of the Department of Research, Information and Collections) and Slindokuhle Ngobese (Collection's Officer), both uMsunduzi and Ncome Museums.

659 Bill Lindsey (email 29.12.2018) clarified: 'Typical of the earlier Keene Masonic flasks like yours, usually with heavy glass ..., what I see is what is called a "glass tipped pontil scar".'

660 McKearin and Wilson 1978, 12-14, 513 (form group I, no. 8).

661 For the terminology of Masonic emblems, see ibid., 591 GIV-1.

662 Ibid.

663 Ibid., 437. McKearin and Wilson $(1978,412)$ further note that 'the eagles on the Masonic flasks' were not given the same 'careful attention' as their twins on early historical flasks (441-444). 
Water Bottle' (Waterfles). ${ }^{664}$ Yet this type of flask with the same volume, design and composition of symbols, Masonic icons on the front and a version of the American eagle on the back, is well known: it was used for liquor, not water; the standard size is a pint and the height usually around $20 \mathrm{~cm}$. Such flasks were produced and distributed in the early nineteenth-century United States and Canada only. That the Pietermaritzburg flask found its way to South Africa makes it a rare exception. ${ }^{655}$ The motif of the American eagle, intended to emphasise the Masons' accord with state sovereignty, was not exclusive to Masonic flasks, but was the predominant image of 'historical flasks' whose production in the United States started around $1820 .{ }^{666}$ According to Helen McKearin and Kenneth Wilson - who published the 779-page standard volume American bottles and flasks and their ancestry in 1978 - the earliest examples of the Masonic flasks were manufactured between c. 1815 and 1830 for communal Masonic drinking. ${ }^{667}$ In the 1830s their production seems to have ceased, linked by McKearin and Wilson to the then widespread anti-Masonic sentiment and, in its wake, the ineligibility of Freemasons for public office. ${ }^{668}$ We attribute the Pietermaritzburg type by analogy to the Keene-Marlboro-Street Glass Works (Keene, New Hampshire), including bottles with the maker's ' $\mathrm{J} \bullet \mathrm{K} / \mathrm{B} \bullet$ ' mark (not yet deciphered), namely the 'comparatively scarce' and quite similar groups of McKearin and Wilson GIV-3 and GIV-4 type ${ }^{669}$ Recently Bill Lindsey, author of a professional US Historical Bottle Website, ${ }^{670}$ clarified that

the McKearin \& Wilson attribution is solid and likely supported by archaeological evidence that was unstated in the book. Much attribution is thanks to the work of Henry Hall White back in the early 1900 s, who excavated many of the old glass works sites including Keene ${ }^{671}$... It [is] virtually certain ... that both sides of your flask are GIV-4. ${ }^{672}$

The new evidence discussed provides further background to the assumption that Retief owned this flask. It seems to be first mentioned in Hofstede (1876), where a (rather inaccurate) drawing of the container is provided in his history of the Transvaal (fig. 13.21) ${ }^{673}$ Evidently Retief's ownership was so well established by the time Hofstede was writing that he felt able to add the flask as proof of the identification of Retief's corpse on kwaMatiwane: ${ }^{674}$ he claims that Retief was recognised by a leather satchel containing the treaty with Dingane as well as 'a green glass canteen with silver fittings' (een groene met zilver gemonteerde glazen veldflesch). ${ }^{675}$ This is highly unlikely, however,

664 Hofstede 1876, opp. p.50; Voortrekker Museum Pietermaritzburg 1912, 83.

665 'I've never heard of any of the regular GIV series of Masonic flasks being found in South Africa or anywhere else but the US and Canada (my area of study ...); the pictured example you sent is the first to my memory' (Bill Lindsey, email 24.12.2018). 666 McKearin and Wilson 1978, 440-491. Further information on Masonic flasks and the distinct GIV-3/4 (Pietermaritzburg) type is provided at https://sha.org/bottle/liquor.htm\#Masonic\%20Flasks, and www.peachridgeglass. com/2012/04/the-giv-masonic-eagle-historical-flask/.

667 See below, 'Retief and Freemasonry in Grahamstown'.

668 McKearin and Wilson 1978, 439-440.

669 Ibid., esp. 102-103, 414-417, 592-593 (quote), GIV-3/-4 (with drawings).

670 https://sha.org/bottle/about.htm

671 Bill Lindsey email 24.12.2018. He added that he has 'to disagree with Bill [Lockhart] for a variety of reasons as to any likelihood that the flask was blown in England'. Lindsey refers here to Lockhart, Schriever, Lindsey and Serr 2016, a joint article in which Lockhart had tentatively attributed the McKearin and Wilson GIV-3 and GIV-4 flasks to John Kilner companies which produced similar liquor containers from 1842 to 1844 in Castelford, Yorkshire.

672 Lindsey email 29.12.2018.

673 Hofstede's drawing of the flask (1876, opp. p.50), reproduced by Butler (1974, 280), has many mistakes: 1) the level crossed by a plumb line, the beehive, the skull between crossed bones and the (sun) rays around the eye and the moon are not represented; 2) the position of sun and moon is inverted; 3) the stairs leading to the mosaic pavement, the mallet next to the right column and the ' $G$ ' in the apex of the arch, and a 'J' on the right-hand column are additional inventions; 4) more stars are added to the original three and their design is overly articulated.

674 See Naidoo 1985, 194-197. Elrica Henning, uMsunduzi Museum, wrote of the claim that she 'grew up with it (word of mouth)', probably one of the most efficient modes to keep such readings of history strong.

675 Hofstede 1876, 49 (both quotes). It is remarkable that the accuracy of Hofstede's statement has never been questioned. 

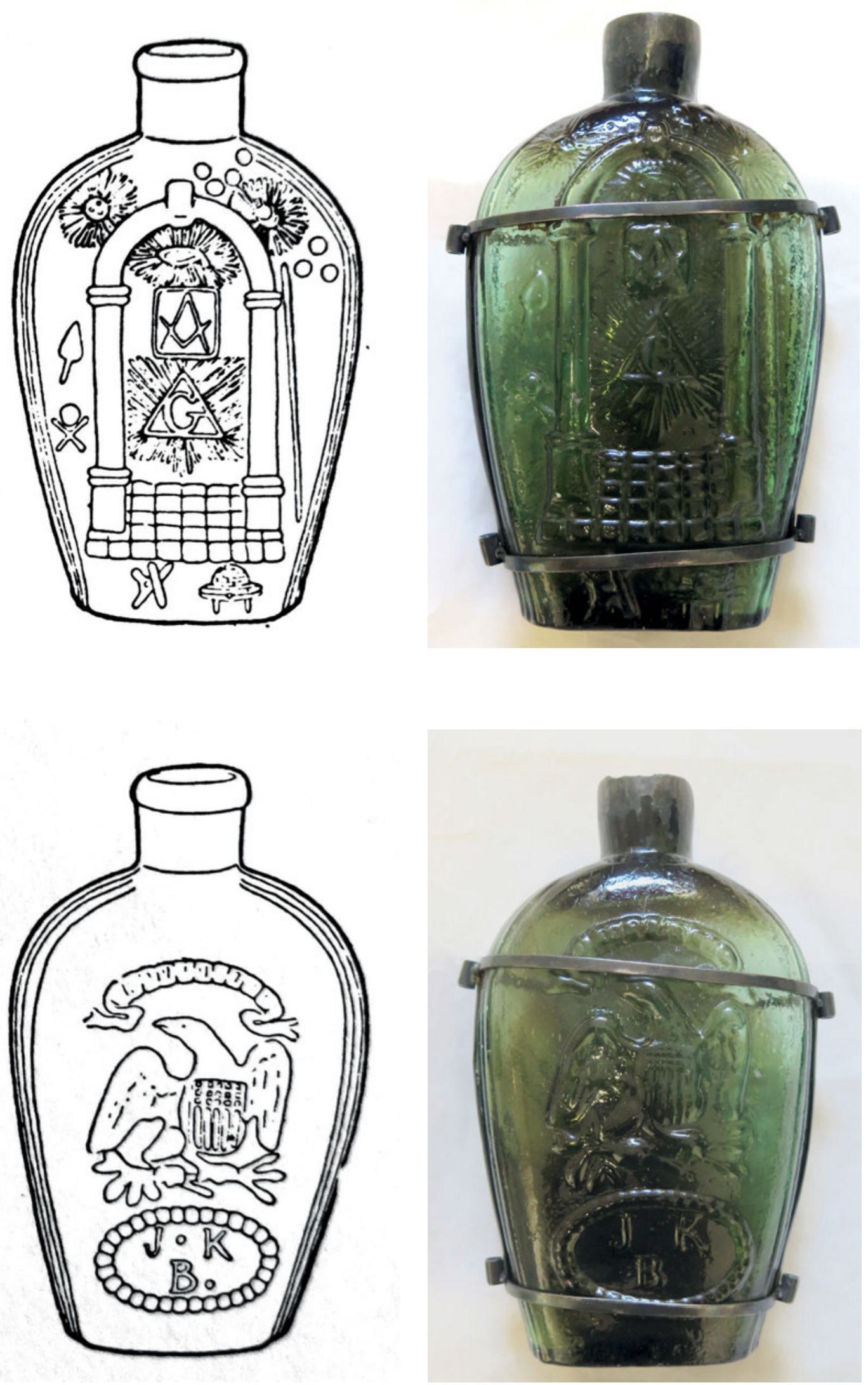

Figure 13.20: Obverse and reverse drawing of GIV-4 type flask (McKearin and Wilson 1978, 593 GIV-4) next to uMsunduzi flask (photos the authors) 
Figure 13.21:

'Veldflesch van Wijlen P. Retief'. Drawing of flask in fig. 13.19 (Hofstede 1876, opp. p.50)

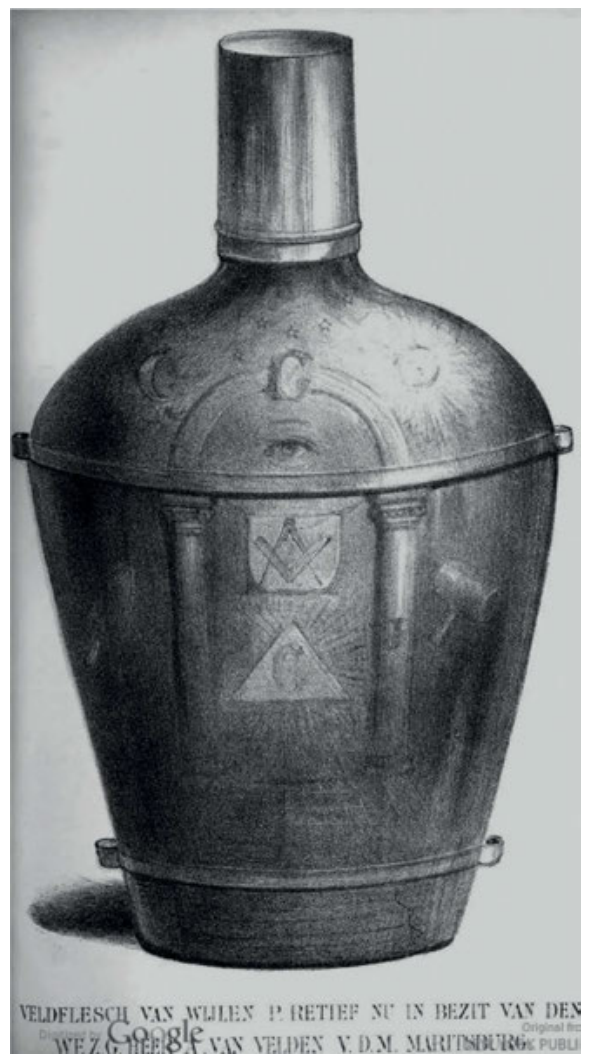

when none of the eyewitness reports mentioned this remarkable object. Moreover, it is hard to imagine that a flask made of glass and in the near pristine condition of this example was one that had survived the brutal force of the Zulu when murdering Retief, especially considering that they if the eyewitness report of William Wood quoted in the main text is correct - extracted his heart and liver in a bestial mutilation of his body.

Hofstede provides further information in the caption of the drawing that assists in reconstructing its history:

Canteen from the late P[ieter] Retief, now in possession of the gentleman Dr A[braham] van Velden, Minister of the Holy scripture. [Pieter]Maritzburg. ${ }^{676}$

As the names and dates of the ministers of Pietermaritzburg are known, A. van Velden must refer to the Dutch Reformed Church minister Dr Abraham van Velden, who was born on 27 October 1844 in Leuven, Belgium, and died on 6 March 1893 in Newcastle, Natal. ${ }^{677}$ In 1863 nineteen-year-old Abraham began to study theology at the Theological Seminary in Stellenbosch, which was founded only four years earlier in 1859 . On 5 March 1868 he was inducted as candidate Dutch Reformed Church minister. A few months later he moved to Pietermaritzburg to be ordained as minister (11 July), where his father, Dr Dirk van Velden (1813-78), had also served as minister for a few months in 1850 and again in 1852. On 22 October 1868 Abraham van Velden married Anna Margaretha Joubert

676 Ibid., opp. p.50: 'Veldflesch van wiljen P[ieter]. Retief nu in bezit van den W[el].E[dele].Z[ij].G[geneesheer]. Heer A[braham]. Van Velden V[erbi]. D[ivni]. M[inister]. Maritzburg.'

677 All personal information is from the Archive of the Dutch Reformed Church (Nederduitse Gereformeerde Kerk $=$ NGK) in South Africa, Stellenbosch, file no. K-Div 1455. We thank Prof. Em. Pieter Coertzen (Faculty of Theology, Stellenbosch) and archivist Karen Minnaar for their kind help. For a list of the Pietermaritzburg NGK ministers, see Groenewald and Bresler 1955, 61. 
(1846-77) from Pietermaritzburg. His confession of alcoholism to the Dutch Reformed Church in 1879 , perhaps related to the early death of his wife, led eventually to his dismissal from his ministry on 30 November that year. ${ }^{678}$ That he was once the keeper of the Masonic liquor flask adds a further layer to its convoluted biography.

Abraham van Velden's vita coincides well with the details provided by Hofstede, and would seem to confirm that the flask was kept in Pietermaritzburg before 1876. As already mentioned, we have good reason to doubt that Retief carried it at the time of his death, and it seems likely that he would have left such a flask in the camp with his other belongings, before he departed to sign a land treaty with Dingane. After his murder in uMgungundlovu on 6 February 1838, custom has it that his possessions passed on to his wife, Magdalena Johanna de Wet Retief (1782-1855), ${ }^{679}$ which would have led to the flask's arrival in Pietermaritzburg when she settled there in 1839/40, although some (ten?) years later she moved to Potchefstroom, where she died in 1855. To affirm the subsequent history of the flask in Pietermaritzburg, it must be surmised that she entrusted the flask to somebody there, though we do not know to whom. Here one may think of her good friends, Susanna and Erasmus Smit, or perhaps the minister Dirk van Velden, father of Abraham, who was the Masonic flask's next recorded owner.

The next mention of the flask is apparently in the catalogue published for the inauguration of the Voortrekker Museum in Pietermaritzburg on 16 December 1912. Here it is listed, one of 339 categorised items of the collection at the time, as the first object under 'XIII Miscellaneous', which repeats the claim that it was found on Retief's corpse, and adds the donors, a point that seems to have gone unnoticed:

Piet Retief's Water Bottle. Found on Piet Retief's remains on Matiwane Hill, Dingaanstad, 12 [sic] months after his murder. Matiwane Hill was the place of execution in the days of Dingaan. Donors: Curators of Theological Seminary, Stellenbosch. Mus. No. $298{ }^{680}$

The last two owners of the flask - the Theological Seminary in Stellenbosch and then the Voortrekker Museum - permit further conclusions. First, the flask was for an unknown time after 1876 and before 1912 in the possession of Stellenbosch's Dutch Reformed Church seminary - Abraham van Velden's alma mater - which by tendency was opposed to Freemasonry (see below). Second, within this timespan the curators of the seminary decided to donate the Masonic object to the Voortrekker Museum, an institution itself intimately related to the early Dutch Reformed Church ministry in Natal. Third, the return of Retief's flask to Pietermaritzburg, named in honour of him and Gerrit Maritz, fits well with the growing awareness of Afrikanerdom, which, we have suggested in our discussion of the frieze, led to its Masonic ornament being underplayed there some thirty years later. ${ }^{681}$

The flask's Masonic links are consistently omitted in the Voortrekker-Museum Pietermaritzburg catalogue, but a remarkable shift in the flask's evaluation can be noticed in the 1930s when one compares the captions for its illustration in the different editions. In the duplicate editions of 1935 and 1937, M. Basson stated as matter of fact:

678 This information was kindly provided by Elize de Villiers, Archive of the Dutch Reformed Church, KwaZuluNatal, Pietermaritzburg (email 28.10.2016).

679 Gledhill and Gledhill 1980, 50-51; Visagie 2011, 415.

680 Voortrekker Museum Pietermaritzburg 1912, 83.

681 A rare exception is Van Rooyen 1938, 163: ‘On the bottle the freemason’s emblems are clearly visible’ (Op die fles is die kenteken van die vrymesselaars duidelik te sien). 
Figure 13.22: W.H. Coetzer. Auction table with (probably Retief's) Masonic flask in 'Uittog uit Kaapland', detail of fig. 1.3. After September 1937 (photo courtesy of Museum Africa, no. $66 / 2194 U)$

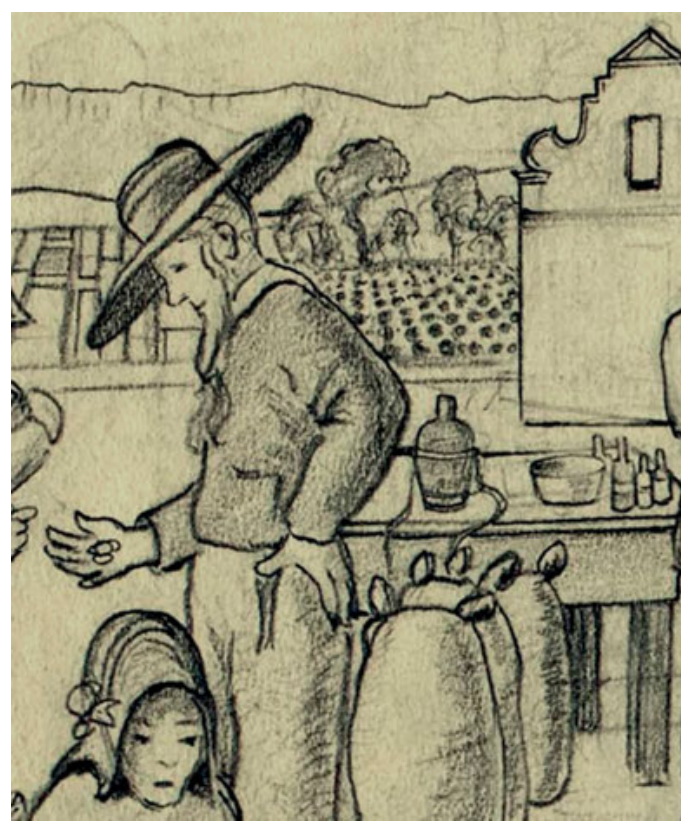

Water flask of Piet Retief found on his remains at Umgungundhlovu, where he and 71 Burgers were massacred by the Zulus on Dec. [sic] 6, $1838 .{ }^{682}$

However, in the enlarged centenary edition published only a year later, Basson had rephrased the caption significantly:

Water flask alleged to have belonged to Pieter Retief who together with 70 Burgers were massacred at Umgungundhlovu, the Kraal of the Zulu King Dingaan, on the 6th Feb. $1838 .{ }^{683}$

In this publication the established reading of the flask - that it was found with Retief's remains at uMgungundlovu as stated by Hofstede in 1876 and the Voortrekker Museum Catalogue from 1912 - was dropped. No explanation is given for why, suddenly, the container's ownership was only 'alleged' and its finding next to Retief's corpse omitted. One is tempted to ask whether the distancing of the Boers from the Masonic flask was linked to the anti-Freemasonry politics of the Dutch Reformed Church and Afrikaner nationalism in general around the time of the centenary of the Battle of Blood River. In the centenary edition of Die Huisgenoot, 'Piet Retief's canteen' is illustrated, but its meaning reduced to 'the only personal reminder of him which has remained', again without a word about its Masonic symbolism. ${ }^{684}$ Around the same time, in his revised drawing of Departure (fig. 1.3), Coetzer depicted a canteen identified by its unusual shape and the added fixing and strap as Retief's flask (fig. 13.22). The artist placed it, clearly visible with other glassware, on the auction table shown in front of a Dutch-gable house. Perhaps Coetzer intended to hint at Retief's central role in the visual narrative through this representation of his flask right at the outset, although he omitted any indication of the decoration.

682 Basson 1935 and 1937, 7.

683 Basson 1938, 15.

684 Van der Walt 1938, 105 with fig.: 'Piet Retief se veldfles - al persoonlike herinnering aan hom wat bewaar gebly het.' 


\section{Retief and Freemasonry in Grahamstown}

Hofstede makes a further claim. The illustration of the flask, he argues, 'shall show my readers that Retief belonged to the order of the Freemasons'; Van Rooyen, on the other hand, records that: 'It has been recounted that the canteen was given to Retief by the Freemasons of Grahamstown when he left the Colony, ${ }^{\mathbf{6} 85}$ which suggests that Retief was not necessarily a Mason himself. This requires further discussion.

The Freemasons were established in southern Africa in the eighteenth century, with the first independent (Grand) Lodge, De Goede Hoop at Cape Town, founded by the Dutch in $1772 .{ }^{686}$ About half a century later, the 1820 settlers from England founded a second Lodge, Albany, in Grahamstown in $1828,{ }^{687}$ which was to be at the forefront of the political separatism movement of the Eastern Cape that from 1833 'challenged the political supremacy of Cape Town and the West'. ${ }^{688}$ A few years later, in 1834, the Dutch Lodge De Vereeniging was formed in Graaff-Reinet, some 240 kilometres north-west of Grahamstown. ${ }^{689}$ Cosmo Grenville Henning explains that there the Afrikaners 'were its most ardent supporters in the nineteenth century, ... but after the exodus of hundreds of families who joined the Great Trek, the Lodge closed down for nearly thirty years' ${ }^{690}$ The public presence of Grahamstown's early Freemasons is further attested to in marketing, for example, when William Rowland Thompson, a local frontier merchant, discussed in Presentation, continued during 1834 his regular 'advertisements' for 'mason's t[r?]owels' ${ }^{691}$ In his biography we also read that in 'January 1834, a notice appeared [in Grahamstown] requesting the subscribers to the Howison's Poort Road to meet at the Freemasons' Tavern as the Committee wished to submit to them the Ordinance which had been obtained for a toll upon the road' ${ }^{692}$

Here we can return to the belief that the distinctive flask we have been discussing not only belonged to Retief but marked him as a Freemason. Important for our context, since Retief was based in Grahamstown before the Trek, are early members of the Albany Lodge. We begin with Louis Henri Meurant, alias Klaas Waarzegger (1812-93). ${ }^{693}$ Born in Cape Town, he founded the Graham's Town Journal in 1831, the first newspaper in the Eastern Cape ${ }^{694}$ After 1834, in partnership with Robert Godlonton, like Meurant a friend of Retief, ${ }^{695}$ the Journal became a mouthpiece for the impending exodus of the trekkers and published, for example, Retief's famous 'Manifesto of the Emigrant Farmers' (2.2.1837). ${ }^{696}$ Meurant was not only politically engaged as journalist, magistrate and Member of Parliament for the Cape Colony, but also a performer and playwright, a strong advocate for the recognition of written Afrikaans ${ }^{697}$ and, rarely mentioned, a Freemason. ${ }^{698}$ Apart from personal ties to other Voortrekker leaders, such as Jacobus Uys and Andries Pretorius, he

685 Hofstede 1876, 49 (... mijne lezers zien zullen, dat Retief tot de orde der Vrijmetselaars behoorde); Van Rooyen, Kultuurskatte 1, 1938, 163 ('Dit word vertel dat dié veldfles aan Retief ten geskenke gegee is deur die vrymesselaars van Grahamstad toe hy die Kolonie verlaat het').

686 Cooper 1986, 16-17.

687 Drury 1928, 6-16; Cooper 1980, 96, 116-121; Cooper 1986, 30-31.

688 Wilson and Thompson 1969, 324.

689 Henning 1975, 111-113; Cooper 1986, 18-19.

690 According to Visagie $(2011,20)$, altogether 409 Voortrekkers left the Graaff-Reinet district to join the treks.

691 Typed biography of 'William Rowland Thompson, Frontier Merchant', p.4; see UCT Thompson A2.1-A.2.14.

692 Ibid., p.5.

$693 D S A B$ 1, 1968, 538-539; Nienaber 1968, 1-11.

694 Meurant 1885, 76-102; Harington 1973, with a critical analysis of the Journal's coverage of the Great Trek from 1834 to 1843.

695 Franken 1949, 376; Harington 1973, 39-40.

696 Reprinted in Chase, Natal 1, 1843, 83-84; see Inauguration.

697 He is regarded as having published, in 1861, the first book in Afrikaans: Zamenspraak tusschen Klaas Waarzegger en Jan Twyfelaar: over het onderwerp van afscheiding tusschen de Oostelyke en Westelyjke Provincie. Cradock: J.S. Bold $\&$ Co.

698 Though it is not known whether he was a member of Albany Lodge, he was given a Masonic burial in Riversdale where he died (DSAB 1, 1968, 539). Gledhill and Gledhill $(1980,110)$ call Meurant 'Retief's friend and fellow-Freemason'. 
was a close friend of Piet Retief. ${ }^{699}$ Two other prominent Albany Freemasons - Benjamin Norden (1798-1876), Master of the Lodge in 1834 and 1835, ${ }^{700}$ and John Mandy (c. 1787-1848), one of the founding members of the Lodge $\mathrm{e}^{701}$ - had intensive business dealings with Retief and helped him in times when he had serious financial troubles, even though the two brethren had filed damage suits against him..$^{702}$ It was Mandy to whom Retief owed payment for 'spirits and other liquors sold and delivered - and for lodging and entertainment furnished and provided by the said John Mandy for the said Peter Retief and at his special instance and request' ${ }^{703}$ Edward Guy Dru Drury reports that from December 1928 to April 1835 the Masons' 'dining hall was Mandy's bottle store, the Freemasons' Tavern', a pub and evidently also an inn, 'used as a sort of club by lodge members' ${ }^{704}$ Since the early brethren often lacked their own premises, a room in a tavern, such as the one provided by Mandy, was regularly used for their ritual meetings followed by communal eating and drinking. On these occasions the Masons purchased their own liquor, or brought it with them, one of the main reasons for the production of the early Masonic decanter flasks. ${ }^{705}$ In 1949 John Lambert Machiel Franken questioned whether Norden's and Mandy's 'merciful succour was related to the fact that Retief had perhaps been a Freemason'. ${ }^{706}$ But he could not uphold this assumption because Drury, author of the Records of the Albany Lodge, had told him 'in person that he had not found the name of Piet Retief in the "Records". ${ }^{707}$ Drury confirmed what Gustav Preller (1875-1943) - the ardent Afrikaner historian, who had accepted the claim that the flask was found with Retief's body - had already deduced in 1912:

In addition, the writer Dr [George McCall] Theal was helpful in investigating facts regarding Retief's freemasonry which, so it seems, was demonstrated by the canteen decorated with Masonic symbols found with his bones. (Although the examination was thoroughly carried out - thanks to the support of Mr A. Silberbauer, Deputy Grandmaster for South Africa of the Dutch Grand Orient - in the archives of the Dutch, French and English Freemasons of the Grand Orient, there is no conclusive evidence that Retief was a member of a former Masonic Lodge). ${ }^{708}$

699 Franken 1949, 429-430; DSAB 1, 1968, 538.

700 Drury 1928, post p.51 'Masters of Albany Lodge, 389'; Franken 1949, 246-248, 295-296, 303; Cooper 1980, $101-103$. See also Marshall 2008, 23, 25-26, 38-39.

701 Drury 1928, 9-10, 13, passim.

702 Franken 1949, 245-247, 301-302, 429-430; Gledhill and Gledhill 1980, 109-110, 112 (with special reference to the Masons' support). On Retief's sometimes successful, but mainly disastrous, financial activities, leading to bankruptcies and numerous damage suits, see the painstaking account by Franken 1949, esp. 125-140 (land speculation), 160-233 (building activities and bankruptcy), 234-252 (cash flows between 1825 and 1833); Gledhill and Gledhill 1980, 46-121, 222-223. For the wider social and cultural network of contemporary Grahamstown, see Marshall 2008.

703 Franken 1949, 430 with note 21a, 532: 'Notar. Aktes van G. Jarvis, deel A0 1837, A.H.G.' .

704 Drury 1928, 15. Between 1828 and 1837 the Albany Masons met in six different locations. The first, 'a room of W[illiam] Wathall', only used for a couple of months, became eventually the 'Masonic Hotel', which burnt down in 1899 (ibid., 15-18 [quotes p.15]; Van der Riet 1974, 54-55 fig. VII 4).

705 Messimer 2011.

706 Franken 1949, 246 ('Ons vra ons ook af of bogenoemde barmhartige bystand in verband gestaan het met die feit dat Retief miskien 'n vrymesselaar was'), complemented by n 58 (p.501): 'See the Masonic symbols on his canteen' ('Vgl. Die vrymesselaarsimbole op sy veldfles, Preller, op. cit., bl. 246').

707 Franken 1949, 501 n 58a ('Dr. Dru Drury het my persoonlik meegedeel dat hy die naam van Piet Retief nie onder die bogenoemde "Records" gevind het nie').

708 Preller, Retief 1917, 292-293 (referring to Theal's Geschiedenis van Z. Afrika): 'Buitendien is dr. Theal skrijwer behulpsaam gewees in die nasporing van feite betreffende Retief s'n vrijmetselaarsskap, wat, naar 't skijn, aangewijs werd deur die veldfles met maconieke emblema daarop, soals op sijn gebeente gevonde. (Ofskoon dié ondersoek egter deurgeset werd - dank sij die hulp van mnr. A. Silberbauer, Gedeputeerde Grootmeester vir S. Afrika van die Ned. Groot Ooste, - tot in die archiewe van die nederlandse, franse en engelse vrijmetselaars Groot-oosten, is daaruit nog nie afdoende gebleke dat Retief lid was van 'n toenmalige vrijmetselaarsloge).' Steenkamp (2009, $160 \mathrm{n}$ 3), however, claims: 'It is a well known fact, first put forward by Gustav Preller in his biography of Piet Retief, that he was a Freemason.' 
Considering the above, it does not seem entirely unlikely that a Mason, such as Mandy or his influential friend Meurant, had given Retief the liquor flask as a personal farewell present when the Boer left Grahamstown to join his fellow trekkers.

\section{Freemasonry and the Dutch Reformed Church}

Retief's personal relationships with Masons are mirrored in their close interaction with Boers in general, which was not then frowned upon by Dutch Reformed Christianity. This is demonstrated by the event involving Thomas Philipps (1776-1859) - who was a founding member and first Master of Albany Lodge (1828 and 1829) ${ }^{709}$ and 'actively encouraged the erection of the earliest Anglican churches in Albany ${ }^{710}$ - being asked by the British settlers to present the 1756 Dordrecht Bible to Jacobus Uys in April 1837, depicted in Presentation, while Meurant acted as interpreter. ${ }^{711}$ In the nineteenth century several ministers of the Dutch Reformed Church had been members of De Goede Hoop Lodge. ${ }^{712}$ Rev. David Pieter Faure (1842-1916), for example, was Provincial Grand Master of this Division for eleven years and a Deputy Grand Master of the Netherlands, although he came to oppose the traditional doctrines of the Dutch Reformed Church, and became a founder minister of the Free Protestant (Unitarian) Church in Cape Town. ${ }^{713}$ Later some of the most distinguished Boers politically were brethren, such as Sir Christoffel Brand (founding member of De Zuid-Afrikaan in 1830 and elected speaker of the first Cape Legislative Assembly, 1854-73, who was Deputy Grand Master National from 1847-74); ${ }^{714}$ Marthinus Wessel Pretorius (president of the Transvaal Republic, 1855-60, then of the Free State, 1859-63); ${ }^{715}$ Johannes Brand (president of the Free State, 186488); ${ }^{716}$ Francis William Reitz (president of the Free State, $\left.1889-95\right) ;{ }^{717}$ General Ben Viljoen (leading commandant in the Anglo-Boer War); ${ }^{718}$ and General Louis Botha (prime minister of the Transvaal, 1907-10, then first prime minister of the Union of South Africa, 1910-19), to name only a few. ${ }^{719}$

However, church dislike 'for Freemasonry had been expressed in the Cape since the start of the De Goede Hoop Lodge'. ${ }^{720}$ It assumed 'full voice at the synod of the newly organised Dutch Reformed Church, which met in Cape Town in October 1862' ${ }^{721}$ When it was discussed whether the theological seminary should move from Stellenbosch to Cape Town, it was argued that 'the youths would fall into the snares of the clique of Freemasons ... There might be one or two stray Freemasons in Stellenbosch but it is well-known there was no city on earth so completely under the influence of Freemasonry than Cape Town'; as a result the seminary stayed in Stellenbosch. ${ }^{722}$ In response to such accusations Mason Christoffel J. Brand declared in 1869:

We form no church: religion, morality and love are the groundwork of our labours and the aim of our actions, because by that we promote the happiness of mankind. Why then should the clergy, and particularly those of the Dutch Reformed Church, act so hostilely against us? ${ }^{723}$

709 Drury 1928, 8-13; Cooper 1980, 96.

$710 D S A B 1$ 1, 1968, 542. Albany, the district around Grahamstown, was the destination of the 1820 settlers.

711 Ibid., 538.

712 Cooper 1986, 150.

713 Faure 1907 (pp.115-122, for his Freemasonry); Cooper 1986, 107-108, 110-111.

714 Cooper 1986, 22-30.

715 Ibid., 23.

716 Ibid., 24.

717 Ibid., 100-101.

718 Ibid., 76-78, naming further leading Boer soldiers and statesmen who had been Freemasons.

719 Ibid., 76-77, 89, 95, 100, 157; photographs of most of the said Afrikaner Freemasons are provided after p.64.

720 Ibid., 149-154 (quote p.150).

721 Ibid., 150.

722 Ibid.

723 Ibid. 
Yet the disapprobation of Freemasonry by the Dutch Reformed Church became more and more extreme in the twentieth century. In April 1931 - the foundation year of the SVK - the Dutch Reformed Church Transvaal Synod in Pretoria condemned Freemasonry by 129 votes to 29 and 'strongly urged members of its community to have nothing to do with masonic lodges ..., not to join Freemasonry and that masons should not be members of church councils', though many were. ${ }^{724}$ Later, the Afrikaner Broederbond mirrored the Dutch Reformed Church opposition to Freemasonry. At the nineteenth Broederbond meeting on 4 and 5 October 1940 a resolution was put forward to reject the Freemason movement and forbid dual membership of the two societies. Although the proposal regarding double membership was not carried, the minutes recorded that 'From the discussions it is clear that the Bondsraad was opposed to Freemasonry, especially its imperialistic character in South Africa'. ${ }^{725}$ Jan Serfontein goes so far as to state that the Freemason movement was the Broederbond's 'enemy number one', because not only was its membership 'much larger numerically' but $60 \%$ were Afrikaans-speaking; it was felt to be imperative to avoid 'young Afrikaners falling into the clutches of Freemasonry and its "denationalising" influence'. ${ }^{726}$

This context of conflicting relations between Freemasonry, the Dutch Reformed Church and Afrikanerdom gives the Masonic flask depicted in the frieze a rather ambiguous status. We surmise that the flask was shown only to identify Retief, and that its Masonic ornamentation was inaccurate and blurred on purpose. In fact it is surprising that the flask, first introduced by Coetzer in his sketch for the Murder of Retief, was not altogether excluded, particularly when one considers Moerdyk's key role in supervising the frieze, given that he was a long-standing member of the Broederbond, as too were many members of the SVK including chairman Jansen, treasurer Lombard and secretary Botha. Apparently the flask seemed indispensable to identify Retief, but the negative attitude to Freemasonry meant that Retief's possible association with the Masons had to be avoided. The reluctance to present the flask fully may be reflected in the delay in finishing its details in the full-size clay panel, until after the figures were for the most part complete (fig. 13.8). It suggests once again that the quest for 'authentic' detail in the frieze, as incontrovertible evidence of the validity of this history of the Trek, outweighed other considerations. The disfigurement of the flask's Masonic ornament in the frieze - something overlooked by scholars ${ }^{727}$ - was evidently, as far as the claim for historical accuracy was concerned, the lesser evil. In the end, the flask's biography, now unfolded, and its adapted representation make the object itself a significant document for the history of the marble frieze.

724 Ibid., 151. See also the damning report published in the Dutch Reformed Church and Freemasonry 1940, and the Freemasons' response to it in Review of report on Freemasonry 1942.

725 Serfontein 1978, 50.

726 Ibid., 174.

727 Alta Steenkamp (2009, 151), for example, in her speculative article ('A shared spatial symbolism: The Voortrekker Monument, the Völkerslachtdenkmal [sic] and Freemasonry') takes it for granted that in the frieze 'Piet Retief's water bottle [is] clearly marked with Masonic symbols'. 